\title{
Transforming governance in telecoupled food systems
}

\author{
$\underline{\text { Hallie Eakin }}^{1}, \underline{\text { Ximena Rueda }}^{2}$ and Ashwina Mahanti ${ }^{1}$
}

ABSTRACT. In this paper we analyze how new actors, interests, and resources become salient to food system governance and how the domain of food system governance transforms as a result. Specifically, we focus on how the boundaries of food systems are redefined and new institutions are developed through the explicit recognition of distal interactions and feedbacks - telecoupling-operating in the food system space. Telecoupling can stimulate new forms of governance, such as the development of codes of conduct and certification schemes, with positive impacts on food and livelihood security; when ignored, telecouplings can exacerbate undesirable social and ecological outcomes in linked systems. We present a typology of telecoupled food systems, highlighting three dimensions of distance that can be present in systems that become telecoupled: social, institutional, and physical. We use that typology to explore the evolution of telecoupling and governance change in two case studies. We associate the tendency for changes in governance that occur in each case with the nature of "distance" in the systems in question: whether the systems are distal in terms of social and/or institutional ties, or in the resource base, or some combination of all three dimensions of distance. The challenge of overcoming distance is not the only issue that affects the possibility of governance change; the cases illustrate that the cultural and economic conditions of the connected systems, the agency of actors involved, and their political and social relations and networks all come to play in enabling governance transformation in telecoupled systems.

Key Words: food systems; globalization; governance; Latin America; sustainability; telecoupling

\section{INTRODUCTION}

Food systems are inherently global, connected by complex webs of information, goods, services, and capital (Goodman and Watts 1997). Today more than ever before, local food systems operate within a regime in which corporate actors play a significant role (UNCTAD 2009, McMichael 2011), and distal consumers' preferences and decisions over market dynamics have large local impacts affecting local ecosystems and livelihoods (Lambin and Meyfroidt 2011). Although the impacts of food consumption patterns on the planet have been the subject of considerable research and attention over the last decades (see, for example, Rockström et al. 2009, Godfray et al. 2010, Foley et al. 2011) the ways in which these impacts feed back into food system governance, institutional arrangements, and ultimately decisionmaking is less understood. These feedbacks incorporate not only the activities and actors involved in food production, processing, distribution, and consumption, but also the actors, resources, and values associated with other domains of concern: environmental conservation, climate change adaptation, human development, migration, and energy innovation, to name a few.

Responding to the prominent role of these distal connections, some land-use science researchers have shifted their focus from territory-based governance to incorporate flow-centered governance as a driver of land use change (Sikor et al. 2013). This shift has shed light on large-scale ecosystem changes, and their impacts on social exclusion and even violence (Franks et al. 2014). In food systems, one could argue, "flow-centric" governance has been the norm in most locations since the colonial era, when the globalization of commodity production was responsible for significant land use change and livelihood disruption in much of the world (Byerlee and Rueda 2015). Yet today new actors are involved in food system flows: supranational organizations such as the World Trade Organization, a diversity of transnational corporations beholden to no one nation, as well as highly organized domestic and international nongovernmental groups
(Ingram et al. 2010). The "flows" that are playing critical roles in food systems today are not limited to traded food commodities, but also incorporate other material and nonmaterial flows, such as humanitarian investments, or human migration, as well as discourses, ideology, information, technology, and know-how (Adger et al. 2009, Oosterveer et al. 2014).

Governance can be defined by the actors and organizations that manage a resource base and define how and what rules of management should be designed and put in practice (Ostrom 2009). Governance thus incorporates not only the institutions, the rules, norms, and regulations that structure interactions, but also the actors involved, and their values, interests, and actions. The growing connectivity and increased availability of information that is integral to globalization allows consumers and civil organizations to demand that their concerns and interests are incorporated into food system governance. As a result, some food system actors are working with civil society organizations to improve production practices and to include ethical considerations, whether social or environmental, in their practices or those of their suppliers (Jaffee and Henson 2004, Auld et al. 2009). These new hybrid institutions formed by collaborations among state, market, and/or civil society organizations provide novel mechanisms to account for the externalities associated with supply chain activities (Lemos and Agrawal 2006). The incorporation of new actors and their concerns challenge the very boundaries of what might be considered to be the resources, actors, activities, interests, and values salient to and necessary for food governance. Thus, adopting the "food system" as the unit for governance allows for an expansion of the functional scope of institutions to incorporate the challenges and externalities associated with the production, distribution, and consumption of agricultural commodities, and the diverse values of its stakeholders. Nevertheless, we have relatively little understanding of the conditions under which such problem-driven institutions emerge and the feedbacks that stimulate changes in governance. 
In this paper, we analyze the conditions under which new actors, interests, and resources become salient to food system governance and how the domain of food system governance may change as a result. Specifically, we focus on the way in which diverse values and interests held by actors associated with a social-ecological system linked to food production become the basis on which the boundaries of the system are redefined and new institutions are developed. We employ the concept of telecoupling, a concept borrowed from the natural and physical sciences, as a heuristic to frame our analysis. In its application to social-ecological systems, telecoupling has typically referred to systems that are linked, even though they are physically distant ("tele" referring to "far, or far off"), which problematizes the understanding of the causal mechanisms that couple them. Through the lens of governance, telecoupling brings attention to the latent "ungoverned" causal interactions and feedbacks between distinct systems, and how (and whether) the eventual acknowledgement of such interactions and feedbacks may alter system governance to enhance sustainability (Eakin et al. 2014a). In this paper, we propose that telecoupling incorporates the idea of institutional and social distance as well as physical distance. This expansion of the telecoupling framework facilitates our analysis of how food systems evolve to incorporate the interests, actors, and geographic spaces associated with issues and resources that have traditionally been considered external to the boundaries of food systems.

\section{TELECOUPLING AND SOCIAL-ECOLOGICAL FOOD SYSTEMS}

Over the last decades, rural sociologists, geographers, and anthropologists have brought attention to the complexity of contemporary food system interactions, arguing that the reorganization of global capital and investment has fundamentally restructured our relationship with food, its place of origin, and its social and environmental impacts (Goodman and Watts 1997, Clapp 2003, McMichael 2011). Scholars of food regime theory have argued that we are now in a new era, a new food regime, in which corporate interests and financial controls are dominant (see Friedmann 1994, McMichael 2001), but one in which there are also new dynamics offering both resistance to corporate food-system control and new economic opportunities for powerful actors to exert their agendas (McMichael 2009, Goodman et al. 2010). This new food regime, named "food from somewhere" by Campbell (2009), is an evolution from the prior global food regime dominated by generic, substitutable commodity chains and the "invisibility of origin" of food, i.e., "food from nowhere." Under the emergent "food from somewhere" regime, efforts are being made to recognize the social and ecological feedbacks between bases of production and points of consumption. Nongovernmental organizations, mobilized consumer groups, peasant movements, or retailers catering to elite segments of society seek to reconnect food to place and identity through new instruments of governance: food audits, commodity traceability, eco-certifications, and labeling schemes. Together these instruments serve to communicate the ecological and social consequences of distant food system interactions, in essence "reembedding" dispersed transnational food systems into specific places and cultures (Campbell 2009).

The organization and coordination of the various activities in an agricultural commodity supply chain, and the implications of power distribution among actors involved in processes of production, consumption, and distribution is the central focus of global commodity value chain analysis (e.g., Gereffi et al. 2005, Auld et al. 2009, Mayer and Gereffi 2010, Lee et al. 2012, Rueda et al. 2017). Recent studies on agricultural commodity roundtables provide some insights into the processes by which supply chain actors collaborate with NGOs to create a shared understanding of sustainability, the environmental and social externalities and spillovers of agriculture (Boons and Mendoza 2010). These multistakeholder initiatives have been evaluated on their ability to establish legitimacy, accountability, democratic capability, and problem-solving capacities (Bäckstrand 2006, Fuchs et al. 2011, Mena and Palazzo 2012). However, the focus has been on the procedural aspects of multistakeholder governance rather than the implications of such collaborations for redefining the functional scope of governance.

For this reason, we turn to a social-ecological systems (SES) approach, which challenges what might be considered the boundaries of food system activities, resources, actors, and impacts (Friis and Nielsen 2017). An SES approach shifts the framing of research from focusing largely on the economic and value-chain activities that are explicitly concerned with food, to the complex dynamics that define the social-ecological systems in which food activities are embedded (Ericksen 2008). In other words, it positions food governance within "problem-determined systems," i.e., systems whose boundaries are determined by the issue of concern, rather than "system-determined problems," i.e., a commodity supply chain (Ison et al. 1997, as cited in Ericksen 2008:237). This perspective is thus distinct from other recent food system analyses in which the commodity chain is the focus of inquiry, and actors and activities are defined according to their centrality in the chain (e.g., Newton et al. 2013).

Telecoupling has been employed to explain how multiple (distal) systems interact, their complex causal pathways and the influence that seemingly unrelated systems exert on each other (Liu et al. 2013, Eakin et al. 2014a). The concept of telecoupling has also been recently employed to describe the interdependency among causal factors in social vulnerability to climatic impacts (e.g., Adger et al. 2009, Eakin et al. 2009, Moser and Hart 2015), the coupled nature of the processes of land use change generally (Liu et al. 2013, Eakin et al. 2014a) and urbanization specifically (Seto et al. 2012), and land-use change and food security interactions (Verburg et al. 2013). Challies et al. (2014) call for enhanced attention to empirical examples of governance for globalizing SESs, and highlight the challenges of making normative decisions about the scales at which systems need to be assessed for their resilience, vulnerability, and adaptability as well as in defining socially desirable food and agricultural social-ecological systems.

To date, empirical research using a telecoupling framework has largely focused on the flow of information, finances, and material resources across geographically distal systems. Other, more intangible linkages, such as values, knowledge, social networks, and institutions are only recently being considered in this literature (Moser and Hart 2015, Eakin et al. 2014a, Oosterveer et al. 2014). One untested hypothesis is that the intangible nature of linkages in telecoupled SES, e.g., new values, political dynamics, information on the performance of attributes of interest, may be in part what produces unexpected outcomes: the sudden recognition that emergent outcomes in one location are 
linked to seemingly unrelated policies, investments, and activities in distant places. These outcomes are then what make the relationships visible and tractable for social actors and subject to governance (Eakin et al. 2014a).

The emergence of new forms of governance in food systems that respond to the linkages described above constitutes the focus of our analysis. New forms of governance can incorporate new actors and organizations (and thus new values, priorities, agendas), novel institutions, and mechanisms of implementation, as well as new resources or resource system boundaries. The boundaries of what is governed are defined by the actors and organizations involved (Ostrom 2009). Food systems, as SESs, comprise resource system(s), e.g., land, water, vegetation, and associated biophysical dynamics; units of resources of specific interest to the food consumers, e.g., corn for food and fuel; resource users, i.e., producers, distributors, retailers, and consumers, dispersed across regions, with different incentives and motivations, and the governance arrangements that link these system elements. The geographic dispersion and connectivity of the actors involved in these systems is of particular interest: their location compounds the challenges of sharing information, lobbying, and networking that enable new forms of governance to emerge (Brondizio et al. 2009). Accelerated processes of globalization and global environmental change have transformed the dynamics of SES and the attributes of what constitute "good governance" in the new millennium: local actors have, in many cases, more influence on global processes than at any point in the past. In many cases the rules and norms intended for specific geographies or economies have unprecedented influence on outcomes at other scales and in other places (Karkkainen 2003, Young et al. 2006, Adger et al. 2009, Eakin and Wehbe 2009).

In our analysis, we study change (and lack of change) in the governance of two food systems: maize and coffee, which become coupled with the global energy and global humanitarian aid systems, respectively, through the lens of telecoupling. We have chosen these two cases because of their global importance to international trade, food security, and sustainability. Both systems play significant roles in the food security of the poor: maize is one of the fundamental staples of human diet across the planet and is still produced by smallholders in most maize-producing nations, while coffee provides cash income to more than 60 million growers around the globe. The production of these crops has substantial impacts on land use and ecosystem conservation in both tropical and temperate regions of the world. Both crops are also associated with significant cultural, political, and economic values in the particular geographies where they are produced and consumed. We explore the recognition of telecoupling related to these crops within a similar historical moment in the Americas: the onset of the neoliberal era of agricultural commerce and the rise of the "food from somewhere" regime. Although the commodities produced by these two food systems have been traded at the global level for centuries, only in recent decades have these systems seen their boundaries expanded to become telecoupled in unique ways, as the cases will illustrate. Nevertheless, despite broad similarities, the evolution of governance in response to the recognition of telecoupling was quite distinct in the two cases, providing an opportunity for case comparison.
In undertaking this case study comparison, we do not provide a comprehensive view of all possible telecoupling types (discussed below), or derive broad theoretical conclusions regarding how different forms of telecoupling will determine specific governance outcomes. Such undertaking would require a larger pool of examples, beyond the scope of this paper. Instead, we aim to use the two cases to explore empirically some of the elements that would appear significant in helping explain the differences observed in governance outcomes. We draw from a conceptual framework, described below, which posits that specific phases occur in the process of societal recognition of telecoupling relationships, providing opportunities for a shift in governance arrangements. The framework creates a temporal structure that we use to delve into the events and outcomes associated with the recognition of and response to telecoupling, as reported in a variety of secondary sources and from our own primary research. The insights from these cases can thus be employed to improve upon conceptual models of telecoupling to provide evidence of some of the mechanisms that link telecoupling structure and dynamics to governance outcomes.

Our analysis thus focuses on the initial conditions within the systems of interest, the phases that evolved to produce telecoupling, and within each phase, the mechanisms by which the telecoupling enabled (or not) the interests and values of new actors to be incorporated into an expanded notion of the boundaries of the food system in question and thus the domain of governance. Our focus on governance arrangements frees us from considering telecoupling solely in distal spatial terms and allows us to analyze the interaction of both social, institutional, and natural resource base distance among systems as challenges in governance. We broaden the scope of telecoupling to consider the possibility of overlapping social-ecological systems, in which either actors or resources are common, yet which share few institutional ties. Through shedding light on the distal mechanisms that trigger social and institutional change, we aim to contribute to an emerging discourse on governance for enhanced food system sustainability. Before analyzing the cases, we introduce a typology that outlines four different initial conditions under which apparently distal processes become coupled. We posit that these initial conditions circumscribe the mechanisms that emerge as significant in the evolution of governance, once actors recognize a situation of telecoupling.

\section{FOUR TYPES OF INITIAL CONDITIONS IN TELECOUPLING}

Telecoupling may be in existence whether or not it is formally and explicitly recognized or understood by social actors. Nevertheless, it is the explicit and conscious recognition of telecoupling that we posit is necessary if governance arrangements are to take into account telecoupled relationships. Thus, we can define a process of the explicit recognition of telecoupling as a series of system interactions occurring at different temporal stages. The systems are necessarily in constant dynamic change; defining the "initial" state is thus only a point for reference to map subsequent shifts in the configuration of system governance in relation to the occurrence and recognition of telecoupling.

We propose four distinct types of initial conditions, e.g., prior to the recognition of a telecoupling interaction, considering, for 
Fig. 1. Typology of possible initial conditions in telecoupled interactions. In each quadrant, we depict a caricature of a social-ecological system, composed of interactions between resource base and a social system. Each analytically discrete social-ecological system is signaled by a rectangle boundary, within which a constellation of actors participates in the use of a resource base. Their actions over the resource, and the resource response to these actions, i.e., flows of goods or resource units, are governed through institutional arrangements (signaled by arrows)

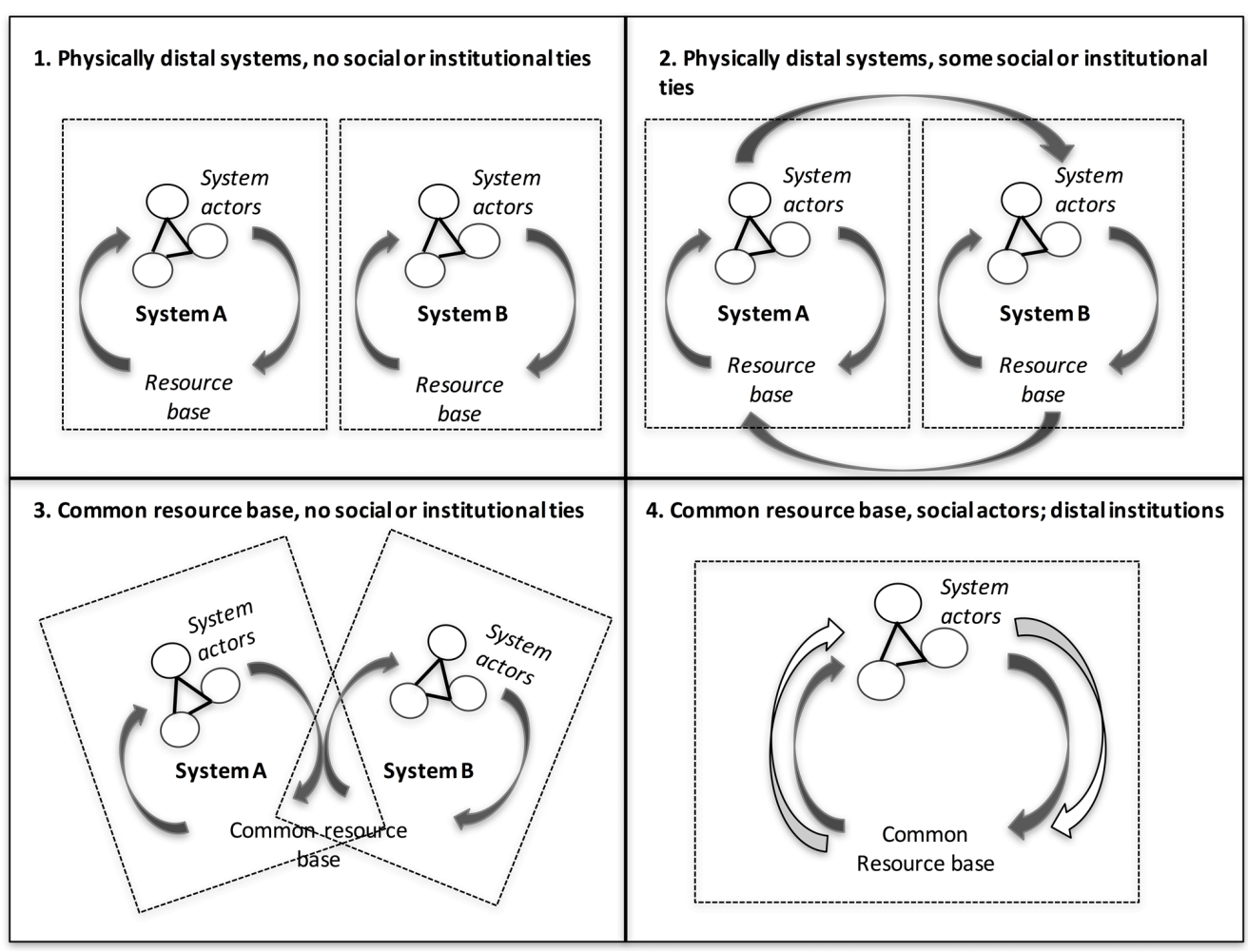

simplicity, two systems that initially are not telecoupled (or for which the telecoupling is latent, or not explicitly recognized). These distinct types provide simple analytical constructs for the purpose of defining system boundaries, initial states, and concerned stakeholders (Fig. 1).

\section{Physically distal systems, no social or institutional ties}

The first type of initial system structure (1) refers to two or more geographically distant and functionally independent socialecological systems governed by different institutional, cultural, political, and/or economic arrangements and actors (Seto et al. 2012, Liu et al. 2013, Eakin et al. 2014a). Using an anecdotal example, this might be the case of rapid land use change and urban development occurring in the United Arab Emirates, fueled by migrant laborers from Nepal. The systems, incorporating a resource base, e.g., agricultural land or urban land; resource users, e.g., farmer households, urban developers, and laborers; and governance arrangements, e.g., land tenure laws, food security programs, labor laws, or economic development incentives, become coupled when profound indebtedness or, alternatively, remittance flows, associated with migrant labor influence trajectories of land use change in Nepal (Jaquet et al. 2016). Nepalese land use change, and the associated effects on food security, would then be telecoupled to urban development in the UAE.
Physically distal systems, some social and institutional ties

The second type (2) refers to two distinct geographically differentiated natural resource systems, e.g., the land, water, and other biophysical resources used for cotton production in periurban regions of Arizona, and for cotton production in China, become linked through some overlapping social actors (resource users, resource administrators) and institutional arrangements, for example, via international trade. This interaction is likely governed by bilateral or multilateral trade agreements and corporate norms and standards in markets. Nevertheless, there are other resource users, for example, urban land developers or suburban water users, who are not explicitly governed by institutions pertaining to cotton. Should change occur in the cotton commodity chain, in our hypothetical example, in access to Chinese markets, there might be unexpected repercussions for labor demand in cotton, and water availability for suburban development in Arizona, as competition for land and water increases. In this hypothetical example, suburban housing development (a system sharing resources with locally produced cotton, but incorporating different resource users and institutional arrangements) may become telecoupled to cotton institutions, actors, and resource base in China, via the dynamics of the U.S. cotton sector. 


\section{Common resource base, distal social and institutional systems} A third type (3) is characterized by two overlapping socialecological systems that share common biophysical resources or fundamental ecological processes, i.e., the resource system, but for which the social actors, i.e., resource users, and associated institutions are largely independent with minimal interaction. In this case, physical distance is not the defining feature; rather, the systems may be operating in the same locations but for a variety of reasons (economic efficiency, politics, history, organizational mandates, and imperatives) share few formal social or institutional relations. Here, as we describe in detail below and has been detailed in the literature on "land grabbing" (see for example, Borras and Franco 2012), we might have a renewable energy sector that, in response to technological developments, begins to seek out land resources for the production of biofuels. These same land resources are already in production for food crops, governed independently by food and agricultural institutions. Under some circumstances, these different socioinstitutional, but common natural resource systems could become telecoupled in the institutional space when ecological and social processes in a specific geography become tied to energy policy in a distant location. In response, there may be new efforts to achieve a shared goal of joint governance for resource management. In this sense, as the telecoupled relationships are recognized, system boundaries dissolve and are redrawn to encompass the expanded actors and institutions that encompass the newly defined socialecological system.

\section{Common social and physical systems, distal institutions}

Finally, in a fourth type (4), there may be large overlap in the resources and actors in two systems, but a lack of a shared system of governance. This situation is common in many complex urbanizing environments in which natural resources (land, water) are managed locally by landowners with institutional ties to rural organizations and national agricultural agencies. However, the same resource base may also be subject to urban laws and norms and associated agencies (see, for example, Lerner and Eakin 2011, and Short 2013). Again, natural resource distance is less of a determinant feature of this scenario. Here, for example, urban policies such as housing densification can have unintended consequences that undermine agricultural land use goals. Or, in more industrial contexts such as the Southwest U.S., processes such as the use of herbicides for controlling weeds by suburban homeowners (governed by household/residential chemical use and practices) can have implications for herbicide resistance and agricultural practices in surrounding peri-urban fields (governed by sectoral and national policies).

In each scenario, following a disturbance to one or more of the systems, telecoupling becomes visible to actors as a potential governance concern when, for example, ecological or social conditions cross a threshold of concern (changes in a resource base condition), new information emerges (challenging existing institutional conditions), or new actors acquire agency (changes in social relations) and are able to shift attention to system dynamics that were previously neglected. Because existing governance arrangements do not initially incorporate the newly recognized intersystem linkages, the disturbance is likely to produce unexpected and thus often surprising outcomes: environmental changes, for example, or impacts on specific livelihood opportunities, consumption processes, or incomes. In some cases, such outcomes produce volatility in markets, consternation in political processes, and even social violence or unrest (Eakin et al. 2010).

\section{Changes in governance in telecoupled systems}

For the purposes of this analysis, we consider that a substantive change in governance, following the recognition of telecoupling, would encompass the explicit incorporation of new actors with distinct values and interests into existing governance arrangements. Thus, creating a reframing of what constitutes the geographic and thematic boundaries of governance to account for telecoupling relationships and outcomes, and/ or the formulation of additional or new institutions to achieve revised performance goals. Ultimately, a significant change in governance would fully embrace the issues raised in telecoupling that were initially considered as external to the food system within existing governance regimes.

Significant change in institutional structure often derives from functional, social, and political pressures: the recognition of performance deficiencies (functional pressure) in existing governance arrangements, for example, as evidenced by loss of productivity in some attribute of value to an organization; the introduction of discordant or diverse values and priorities into governance (social pressure); or/and shifts in power and agency within an organizational domain (political pressure; Oliver 1997, Dacin et al. 2002). We see these three forms of "pressures" as interacting in complex ways in the context of telecoupling, given that the sources of pressure, the actors receptive to pressure, and the scope of existing institutions and governance may be characterized by physical or social distance. For example, the entry of new actors into an arena of governance may be provoked by the concern of such actors over functional changes ("functional pressure") in specific system attributes (biodiversity, farmland, social welfare). These actors can enable new values, priorities, and agendas (e.g., "social pressure") to enter an existing policy arena (Dacin et al. 2002, Brondizio et al. 2009, Bodin and Crona 2009). For such social pressure to be effective, these actors must have the capacity for action and mobilization within that existing arena (capacity to exert "political pressure"). As Dacin et al. (2002) argue, incumbent governance arrangements can meet these pressures with resistance or legitimization. How the pressures for institutional change are received is affected by the construction and translation of shared meanings, the agency of specific actors, and power differentials in existing social networks.

Extending these insights about institutional change to the analysis of multiple systems interacting in telecoupled relationships, we posit that there is likely a sequence of temporal phases that condition the emergence of functional, social, and political pressures, and thus the potential for governance change (Eakin et al. 2014a; Fig. 2). First, in order for a disturbance in one system, defined by Liu et al. (2013) as the "sending system," to cause unexpected outcomes in other (receiving) systems, the sending system must have disproportionate influence or control over intersystem linkages, and the "receiving system" would need to be particularly sensitive to the disturbance. In other words, the sending system dominates the flow of information, economic resources, material flows, etc., and the receiving system is particularly dependent on these flows, making it acutely sensitive to changes in its dynamics. For example, in commodity systems 
Fig. 2. Conceptual model of how the recognition of telecoupling may trigger change in governance.
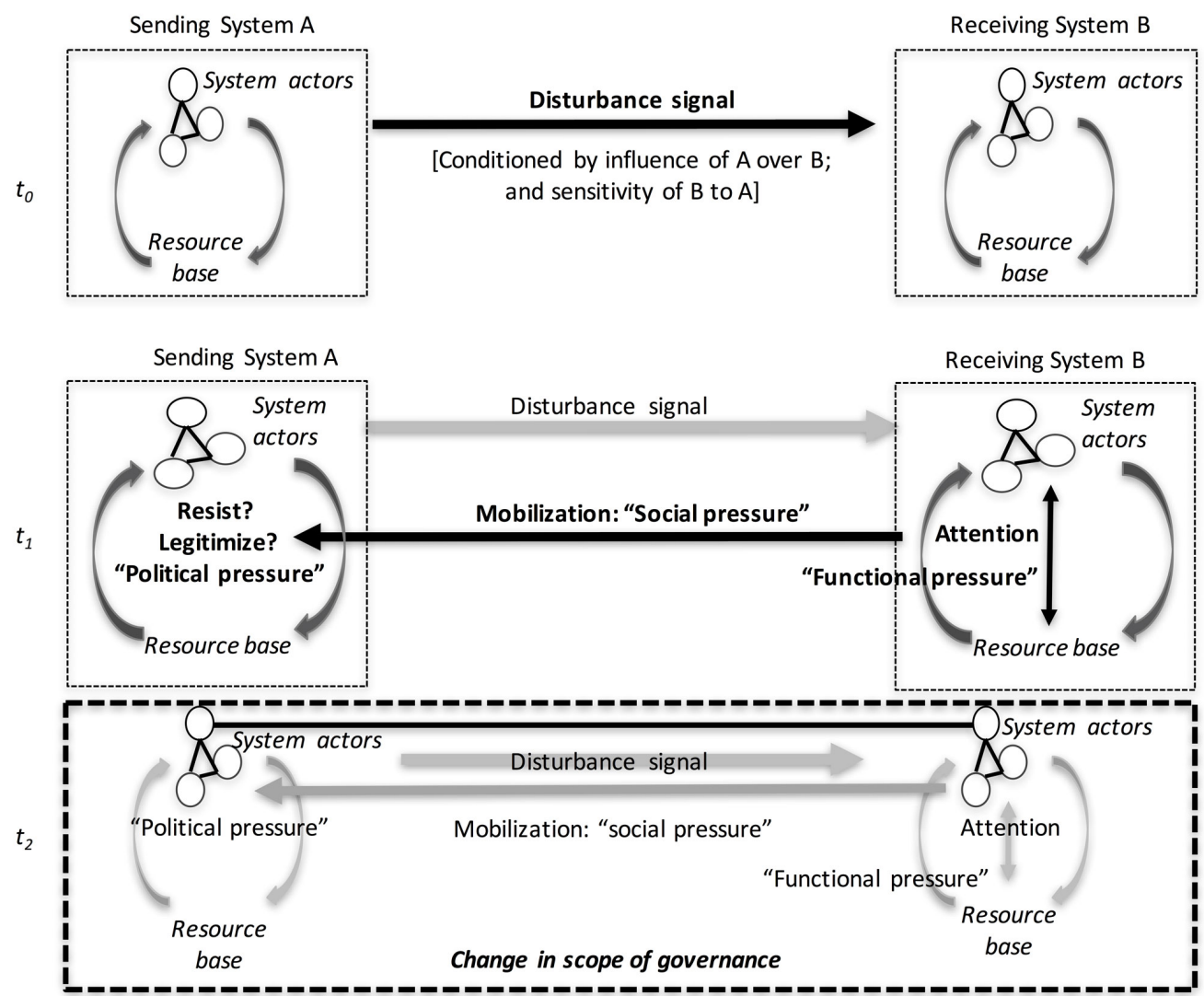

where one region dominates the supply chain, and the commodity is particularly critical to food security in a second region, that second region can be described as been particularly sensitive to the influence of the first (see also Fraser et al. 2005 for a discussion of connectivity, dependence, and food system sensitivity).

Second, the disturbance in the sending system needs to create a change in the receiving system that is recognizable and salient to actors in that system: in other words, a shift in system state that significantly affects attributes of social, ecological, political, or economic value, e.g., the performance of these attributes, to a particular set of actors. These actors then may draw new or unprecedented attention to the unexpected outcome and its potential causal linkages, creating a source of "social pressure." Finally, in order for such attention to affect the structure or process of governance, there must exist a mobilization capacity, a capacity of key actors to act on the changes they have observed that concern them, and exert influence on the existing system of governance, e.g., have the ability to exert political pressure. In food systems, this capacity for mobilization may be, for example, associated with new cross-scalar networks of nongovernmental actors and civil society organizations, i.e., Via Campesina, the international Food Sovereignty or Slow Food movements, or international bodies with policy influence, such as the Food and Agricultural Organization of the UN, or one of the research institutes associated with the Consultative Group on International Agriculture Research (CGIAR), or private sector associations of food retailers or particular commodity chains with specific weight in economic activities. Ultimately, the potential for significant shifts in governance is also dependent on the receptivity of actors within an incumbent regime to embrace and legitimize change, rather than dismiss, ignore, or resist such pressures (Dacin et al. 2002).

\section{CASE STUDIES}

The proposed conditions on governance change described in the previous section are as yet untested. In the sections that follow, we describe two cases of food system telecoupling, applying the telecoupling definition and heuristic described above. We focus on the social-ecological production of maize in Mexico, and the coupling of the coffee commodity market to humanitarian aid system internationally, and its implications for governance of coffee globally and in Colombia. As stated above, these two commodity systems are of crucial importance for rural households in both countries and help us explore how social and environmental outcomes in these two locations are associated with stimuli in distant locations, and the implications that this coupling has for changes in food system governance. These cases are drawn from our ongoing field research and from the availability of additional published empirical research and secondary data. To elucidate the nature and consequences of telecoupling, we identify prior conditions, a "trigger event," and responses in each case. We focus, however, on trajectory of governance that followed the initial recognition of telecoupling 
Fig. 3. Telecoupling of U.S. Corn and Biofuel System to the Mexican Maize System. At $t_{0}$, the Mexican maize system is largely independent of influence of the U.S. energy system. At $t_{1}$, institutional linkages between the U.S. Corn and U.S. energy system are in place; these linkages transmit a signal of change to Mexico. At $t_{2}$, the telecoupling of U.S. Corn Ethanol to the Mexican Maize system has contributed to changes in governance and institutions in Mexico, but has not generated a feedback to the U.S. agriculture-energy system.
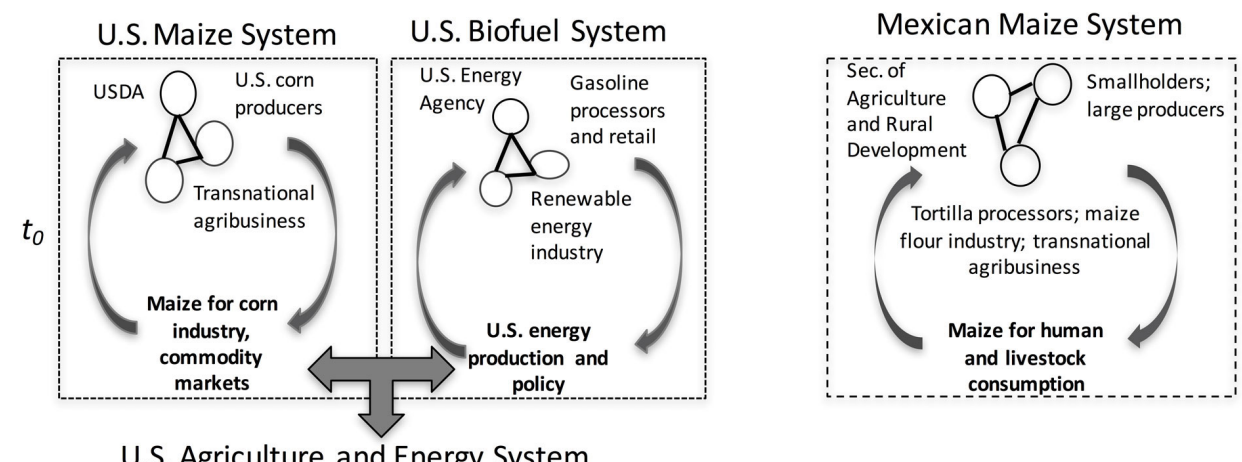

\section{U.S. Agriculture and Energy System}

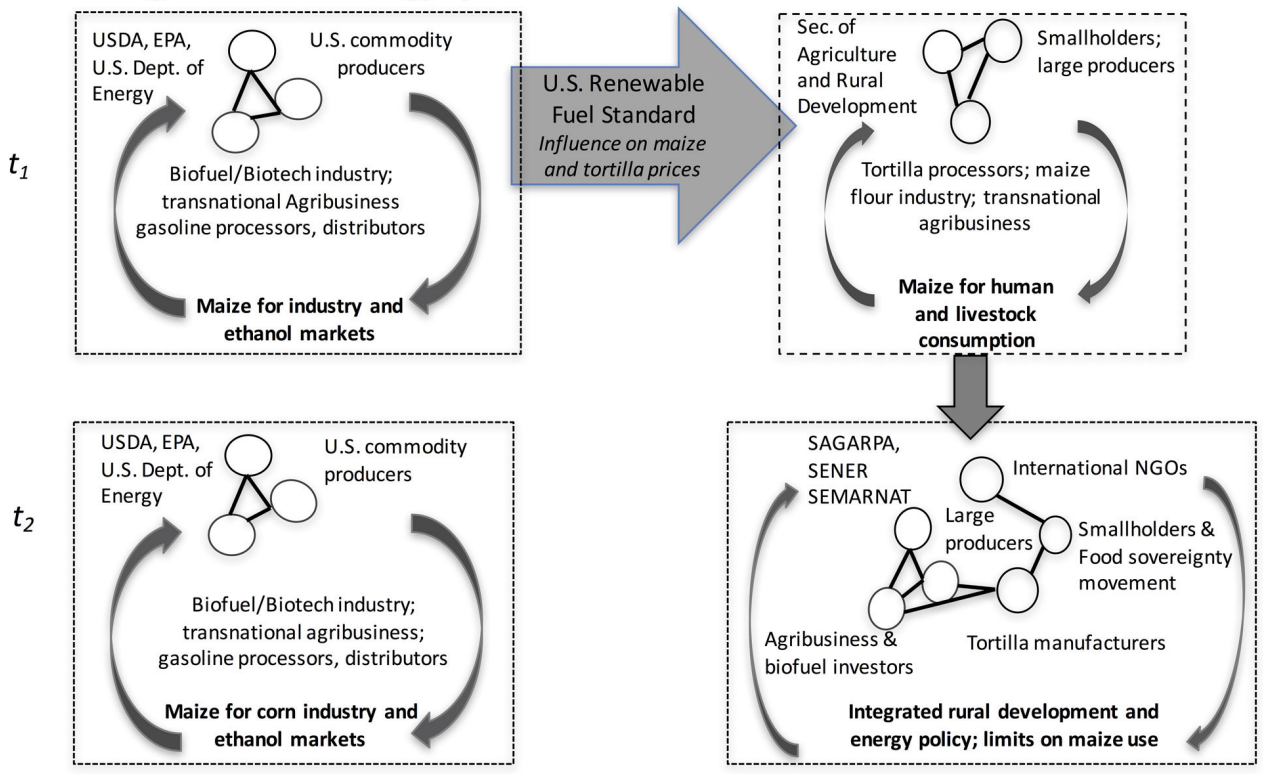

of some element of interest in each system with socially, institutionally, or physically distal processes and events, exploring the conditions that led to change (in the coffee case) and lack of change (in the case of maize).

\section{Mexican maize system}

Maize (Zeas mays L.) is an iconic crop in Mexico. It is widely believed that maize was first domesticated in what is now a semiarid valley of central Mexico (Piperno and Flannery 2001). Maize today occupies more than half the planted area in Mexico, involving over 2 million producers, and constituting $43 \%$ of household grain expenditures (SAGARPA 2007). Maize is not just the primary component of Mexican diets (in the form of the tortilla); it is also a political and cultural symbol (Baker 2013): it is associated with the emancipatory politics of the Mexican Agrarian Revolution, and with Mexico's indigenous traditions and origins. It is the primary symbol of the "countryside" ( $\mathrm{el}$ campo) and as such, a symbol of the rights and traditions of Mexico's large rural population that has otherwise often been marginalized in development investments.

The telecoupling that is the subject of this case study is between three systems that have become integrally linked in two phases (Fig. 3): (a) the Mexican maize system (incorporating actors, resources, and institutions involved in production, processing, distribution, and consumption of maize); (b) the United States yellow corn production system; and (c) the renewable energy sector of the United States.

The Mexican maize and U.S. corn systems have long shared a history of economic governance. In the early 1990s, these two commodity systems thus could be considered to be a "type 2 " of our telecoupling typology: distal geographies governed by some established institutional arrangements and market mechanisms. These economic linkages became more closely integrated with the 
signing of the North American Free Trade Agreement (NAFTA) in 1994, which marked a watershed in contemporary maize policy for Mexico. As a crop central to national food security, Mexico's policy focus of the 1970s and 1980s was to ensure national selfsufficiency in maize through production incentives and trade barriers, limiting the country's dependence on foreign (U.S.) imports (Austin and Esteva 1987). The policy reforms that preceded and accompanied the implementation of NAFTA shifted the focus of national policy from self-sufficiency to free trade and greater efficiency in national production (González Merino and Casteñeda Zavala 2008). The price of white maize was deregulated and set on par with the price of U.S. yellow corn grade 2, traded in Chicago (see Appendix of Appendini 2014 for a discussion of the pricing policies and industrial, but not cultural, substitutability of white and yellow corn). By 2006, commercial maize farming in Mexico had become highly geographically concentrated in the state of Sinaloa (Sweeney et al. 2013), and Sinaloan maize supply began to dominate domestic markets for human consumption (Davenport et al. 2016). Mexico was importing about $23 \%$ of its total domestic consumption, largely in yellow maize, for livestock feed. Almost all, over 95\%, of this maize was being imported from the United States.

\section{Trigger of initial telecoupling of the U.S. corn and U.S. energy} systems

In 2005, a significant change occurred in U.S. energy policy with the adoption of the Renewable Fuel Standards (RFS) as part of the Energy Policy Act. In 2007, an amendment to the RFS mandated that total national consumption of biofuel reach 36 billion gallons by 2022. In 2002, for the first time, the national Farm Bill (the primary instrument of U.S. agricultural policy) incorporated incentives for corn-based ethanol production and processing, effectively uniting the institutions of farm development and land use with national energy security institutions (Hill et al. 2006). The subsequent Farm Bill (2008) furthered this policy by providing payments to farmers who allocated their harvests to ethanol markets. In essence, the U.S. corn and U.S. renewable fuels systems (initially representing "type 3" of our typology above) were now coupled.

The combined effect of the RFS and the supports offered through the Farm Bill was a dramatic increase in corn-based ethanol production and processing, from 4 billion gallons in 2005 to 13.2 billion gallons by 2010 . In 2005 , just over $10 \%$ of the U.S. corn harvest was diverted to ethanol production; by 2010 this figure was $40 \%$ (Hill et al. 2006). Much of the corn diverted to ethanol was at the expense of grain exports, which declined from 2.1 million bushels to 1.8 mill bushels over the same period, a decline of approximately 14\% (USDA ERS [various years]). The U.S. has a particularly prominent functional role in global corn trade: the U.S. is the world's largest supplier of maize in global markets, representing on average $60 \%$ of global maize trade over the period $2003 / 2004$ to $2007 / 2008$. Nevertheless, exports typically are comparable to only $15 \%$ of domestic maize demand. This makes countries importing U.S. corn particularly sensitive to change in U.S. domestic market conditions (and not vice versa).

Transmission of the signal and disturbance in a third system: Mexico's maize system

An unexpected consequence of the coupling of U.S. corn and energy systems was the transmission of energy policy incentives into the Mexican maize system. This second phase of system coupling became acutely apparent toward the end of 2006 when international maize grain prices began to rise precipitously in response to a complex interaction of the effects of the U.S. RFS, adverse climatic conditions affecting yields, a spike in global oil prices, and speculation, against a backdrop of rising grain demand and low global stocks (von Braun 2007, IATP Trade and Global Governance Program 2008, Clapp 2009, Piesse and Thirtle 2009, Headey 2011). The liberalization of corn under NAFTA was fully implemented in 2008 and it was expected that Mexico would import increasing amounts of corn to substitute sorghum for livestock feed in the context of the market liberalization (Hoffman et al. 2007). The sensitivity of Mexico to the global price spike was conditioned not only by the fact that domestic and U.S. maize prices were now undifferentiated in pricing policy, but also by the concentration of national production in a handful of states (dominated by the state of Sinaloa) and the commercial maize market and maize flour processing industry in the hands of a small group of transnational agribusinesses (Reyes Guzmán 2007, Keleman and García Rañó 2011). Directly competing with U.S. maize imports, maize prices in Sinaloa shot up. Market consolidation within Mexico amplified the signal of the price shock within domestic markets (Davenport et al. 2016).

By January 2007, tortilla prices had increased $72 \%$, affecting not only the large urban consumer class in Mexico City, but also rural residents, who also depended on purchases of tortilla dough to satisfy their consumption needs (Keleman and García Rañó 2011). The sudden, and largely unexpected, rise in tortilla prices sent residents of Mexico City to the street in protest. Average weekly household expenditure on tortillas exceeded $20 \%$ of the regulated minimum salary, affecting poor urban consumers most directly (González et al. 2007, Keleman and García Rañó 2011). The rapid rise in tortilla prices also produced an inflationary pressure on the consumer price index, with consequential negative implications for household food expenditures (Reyes Guzmán 2007). According to one estimate, corn-based ethanol expansion in the U.S. costs Mexico over $\$ 1$ billion in increased import costs (Wise 2012).

\section{Attention and mobilization}

Public attention to the rise in tortilla prices and its impact was large, not only because tortilla consumption represents a substantial portion of the calories and expenditures the urban poor. The affordability of tortillas is of political, economic, and ultimately symbolic importance. Mexico's conservative President Calderón had just assumed office by a narrow margin when the tortilla prices spiked; Mexico City, where urban tortilla consumption is concentrated, had overwhelmingly voted for the opposition party. New activist organizations were formed, such as Sin Maiz, No Hay Pais (Without maize, there is no nation, http://sinmaiznohaypais.org), protesting the price spikes and advocating for maize as cultural heritage. The public protests garnered significant media attention and sympathy in the leftleaning urban middle class. The Calderón government responded to the crisis by convening a national "pact" with tortilla industry representatives to establish a (voluntary) price ceiling on tortillas and maize flour (Keleman and García Rañó 2011). The government also waived import tariffs on white corn (used primarily for tortilla manufacture), and agreed to closely monitor speculation. Although smallholder maize farmers demanded 
increased public investment to respond to the tortilla crisis (Melgar and Contreras 2008), little changed in production investments for smallholders (Appendini 2014).

Somewhat ironically, given the perceived adverse effects of rising corn ethanol demand on food prices, policy makers in Mexico initially moved to create new linkages between the Mexican farm sector and U.S. energy sector. In April 2007, the Mexican congress approved the Law for the Promotion and Development of Bioenergy (Ley de Promoción y Desarrollo de Bioenergía). This law was designed to mobilize Mexico's agricultural sector to produce not only corn- and sugar-based biofuels for national use, but also to help meet the U.S. biofuel mandate via export of biofuel to the U.S. Nevertheless, the law's promotion of Mexican maize for biofuel use produced vocal protest among some national smallholder farm associations (who saw little opportunity of their members accessing ethanol markets, and instead preferred support for national food sovereignty), international NGOs, i.e., Greenpeace and Oxfam, and environmental groups (Muñoz Ríos 2007). In response to considerable debate and critique in the media in the wake of the Tortilla Crisis, the law was subsequently modified (Oct 2007) to exclude the use of maize as a source of biofuel, unless there was national production in excess of human food demand (González Merino and Casteñeda Zavala 2008).

\section{Feedbacks in governance}

Although U.S. ethanol expansion was not the only driver of global maize price increases in 2007, the crisis affected the discourse and ultimately the institutions in Mexico concerning national food sovereignty and bioenergy. The outcry raised by rising tortilla prices appeared to threaten political stability, and was seen as an affront to cultural values. To date, restrictions remain on the use of Mexican maize for biofuel. There is little indication that the crisis has led to any substantial change in the governance of maize production or trade. In fact, if anything, the crisis only reinforced Mexico's commitment to maize imports and commercial maize promotion in the northern state of Sinaloa (Eakin et al. 2014b). Sinaloa continues to supply approximately $20 \%$ of national maize production, and to dominate the winter irrigated market (SIAP 2017). In 2017, tortilla prices are once again on the rise pressured by increasing fuel prices, the devaluation of the peso against the U.S. dollar, and the sensitivity of Sinaloa's prices to commodity market volatility in the Chicago Board of Trade (see, for example, Webber 2017).

Although there were feedbacks and repercussions for Mexican policy, neither the Tortilla Crisis, nor the global food crisis more generally, has had an impact on the governance arrangements associated with U.S. farm and energy policy. To the contrary, one analysis found that between March 2008 and March 2011, ethanol supply and demand accounted for $23 \%$ of variation in the price of corn, and that $16-17 \%$ of gasoline price variation can be attributed to volatility in ethanol and corn markets (McPhail and Du 2012). The most recent version of the Farm Bill, passed by the U.S. Senate, maintained its subsidies for corn ethanol production and processing, and 2015 federal budget allocations continue to strongly support corn ethanol. According to one consumer watch group, the continued energy supports have now been supported by heavy investment (totaling over $\$ 22$ million) of the corn ethanol lobby, a group that now integrates both farm sector representatives (American Farm Bureau), the biotech industry (Biotechnology Industry Organization), and transnational agribusiness (Cargill, ADM; Taxpayers for Common Sense 2013).

\section{The coffee system after the crisis of 1989: from the "latte revolution" to corporate commitments for sustainability}

Coffee is one of the most heavily traded commodities in the world. About 60 million people, mainly in tropical regions, are involved in the production of more than 8.5 million tons of green coffee every year. Brazil, Vietnam, and Colombia are the main producers of coffee, Brazil and Colombia being the largest producers of mild Arabica coffee, considered of higher quality than the Robusta variety. North America, Europe, and Japan are the largest consumers, although the more dynamic markets are in the emerging economies of Eastern Europe, Brazil, and even China and India. The case of coffee illustrates how two systems, which were initially only linked by the location of the resource base and their users, became coupled through international institutional and social networks. These two systems can be described as the coffee social-ecological production and trade system, on the one hand, and the humanitarian aid system, devoted to support poor rural households across the developing world, on the other. In this sense, the systems resembled the type 3 scenario: different institutional arrangements and actors invested in the same or closely associated geographic attributes.

The actors of the first system are characterized by producers, traders, manufacturing companies, consumers, and their governments, that determine the terms of trade among those actors. In terms of producers, there are more than 30 countries in tropical areas growing and trading coffee. Coffee is usually grown by smallholders, i.e. "suppliers." Manufacturing has been historically dominated by a few companies that roast, pack, label, and sell coffee through retailers. These companies are located predominantly in North America, Europe, and Japan. The governance system for the coffee value chain was, between 1962 and up to 1989, the International Coffee Agreement (ICA). The agreement was reached between the largest producing and consuming countries and determined a fixed quota of production to be allocated to each country. Producing countries, in turn, developed local institutions to stabilize domestic prices, known as coffee boards, that taxed exports in times of high prices to subsidize the price when they were low. The coffee agreement ended, under the pressure of the U.S. government, and national boards were dismantled (Muradian and Pelupessy 2005). The fall of the agreement was followed by substantial increases in production from Brazil and Vietnam that flooded the market, further reducing the price and contributing to the collapse of most national boards (Muradian and Pelupessy 2005).

The connection between coffee trade and rural livelihoods had been acknowledged by actors in the agreement: manufacturing companies in the North, the governments of those countries, producers' associations in the South, and their governments. Through regulation in the market they produced a loose governance structure that led each national government to design the mechanisms through which the benefits of a restricted market were going to be allocated.

The second system in this case is the humanitarian aid system, which in the 1980s comprised public and private organization in the North (the "donors") and rural households in the South (the "beneficiaries") who receive aid, given their extreme poverty and 
Fig. 4. Telecoupling of the coffee system and international humanitarian aid networks: the case of Colombia. In $\mathrm{t} 0$, the global agro-economic coffee system operated with independent actors and institutions from the humanitarian aid system (type 3 telecoupling). In $\mathrm{t}$, the collapse of the International Coffee Agreement (ICA) provokes a change in actors, agendas, and institutions, as represented by the transformation of coffee governance in Colombia. The social-ecological coffee production system becomes governed simultaneously by local institutions, such as Colombian Coffee Growers Federation (FNC by its Spanish acronym) but also by distal governance systems (the environmental and humanitarian NGOs in North America and Europe). As noted in the text, this domestic transformation was not replicated in all countries: here we illustrate the case of Mexico for contrast.

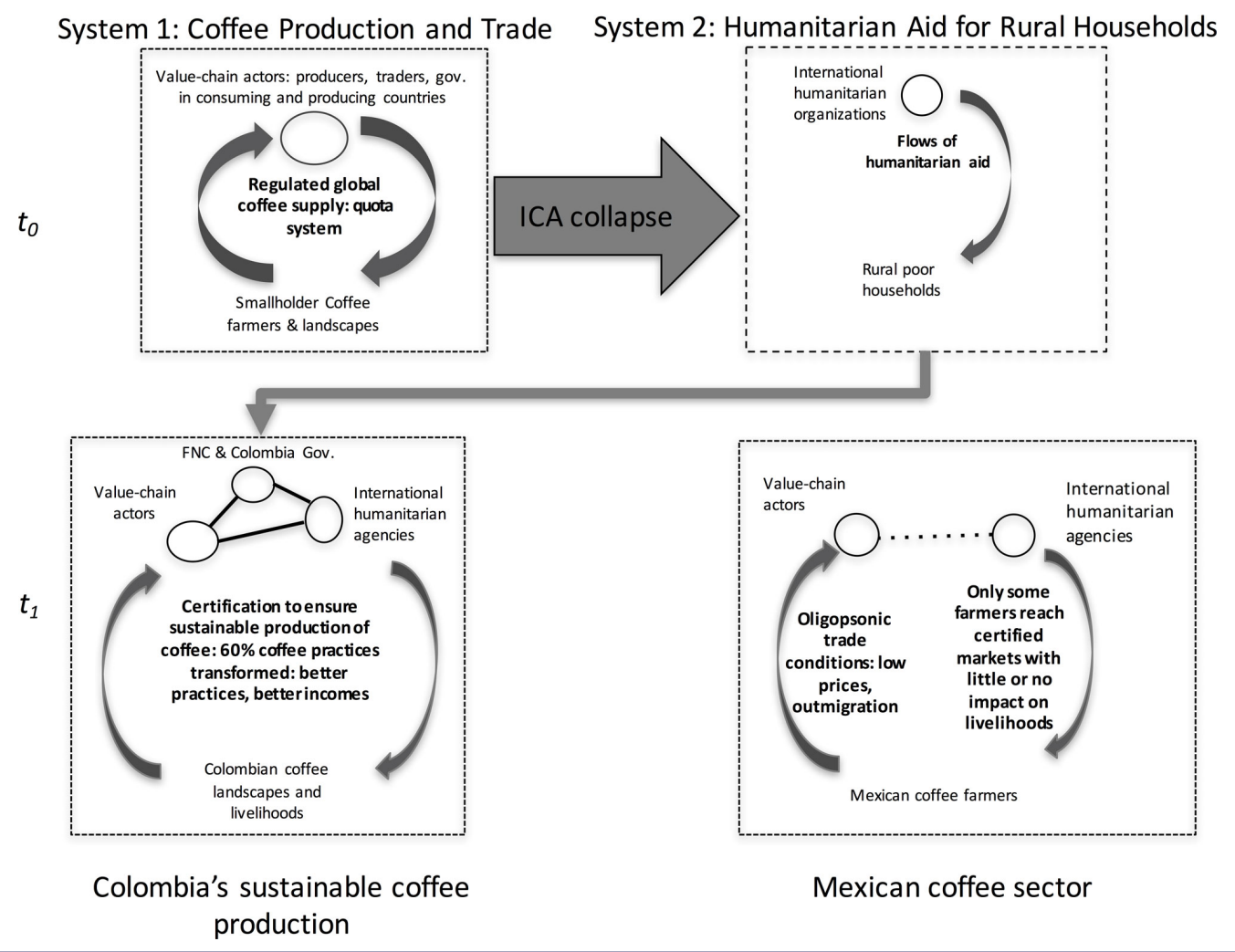

fragile livelihoods. Humanitarian aid organizations for developing countries were formalized and grew considerably after the postwar period, when intergovernmental aid organizations were organized under the auspices of the United Nations (Paulmann 2013). The war marked a transition between the belieforiented organizations that had been active for centuries, to the formalization of aid organizations with defined purposes, professional personnel, and budgets. These organizations proliferated in the 1980s with the expansion of nongovernmental organizations with global aims. The resource base for this system is the social-ecological rural landscapes in the South where poverty is concentrated and households depend on rural assets for their livelihoods (Fig. 4).

\section{Trigger for change}

Under the liberalization doctrine of the 1980s and 1990s, the coffee quota system was dismantled and the ICA collapsed as the primary mechanism of international governance. Muradian and Pelupessy (2005:2029) conceptualize the breakup of the agreement as a "governance failure," in which parties were unable to anticipate the catastrophic consequences of their decision. When the ICA broke, producing countries, especially those offering mild coffee such as Mexico and Colombia, failed to restrain their supply. The national boards had collapsed across the developing world, with a few notable exceptions, and thus coffee growers were left to the ups and downs of international trade. Free market conditions, support from local governments, and multilateral funding for coffee expansion, particularly in Brazil and Vietnam (Giovannucci and Ponte 2005), further depressed the price of coffee. Prices reached a historical minimum in 2001, falling from an annual average of US\$1.17/1b in 1989 to US\$0.71 in 2001, adjusted by inflation (Fig. 5).

Transmission of signal and resulting disturbance in rural livelihoods

As a result of the disruption to the international market, smallholders around the world, the backbone of the coffee industry, suffered a dramatic decrease in their standards of living, spawning a humanitarian crisis (Ponte 2002, Varangis et al. 2003). In Colombia, the Fondo Nacional del Café, Colombia's national 
coffee agency, went bankrupt, having spent most of its assets in trying to compensate farmers' income during the long crisis. In the early 1990s coffee was still the main employer in rural areas, generating close to 1 million rural permanent jobs, representing $40 \%$ of rural employment, $55 \%$ of the total export value, and $5.3 \%$ of GDP (Cárdenas 1993). Coffee production fell by $44 \%$ between 1991 and 1999, and consequently unemployment, poverty, and malnutrition increased in the coffee regions. By the end of the period, coffee production was not considered profitable for at least 23\% of producers (Perfetti del Corral et al. 2002).

Fig. 5. International price of mild Arabica coffee: New York Stock Exchange, Monthly average (US cents/lb 1985-2015) in real terms (CPI 1982-1984=100). Source: International Coffee Organization (ICO) for coffee prices, and U.S. Department of Labor, Bureau of Labor Statistics for the Consumer Price Index (CPI).

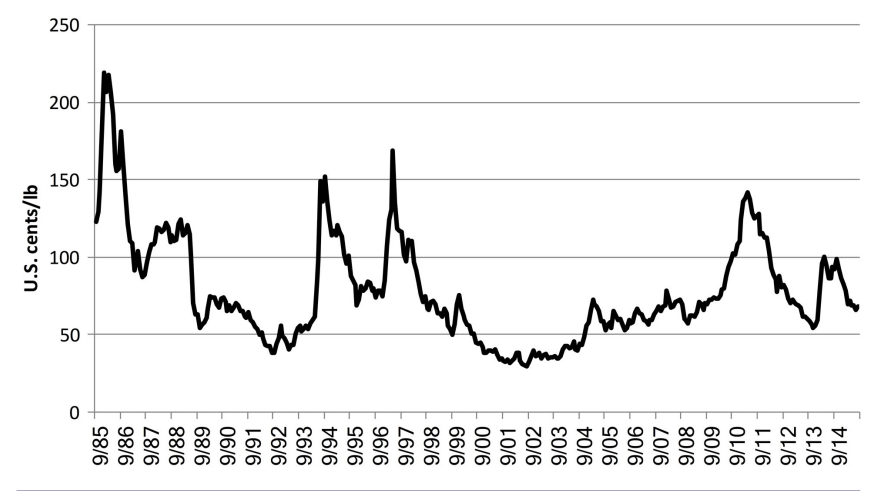

Attention and mobilization

Since the 1960s, humanitarian aid organizations had been concerned with helping rural households by responding to developing countries" cry for a doctrine of "trade no aid"; in the early 1990s they grew considerably worried about the deteriorating conditions of coffee producers around the world (Raynolds 2000). Internationally, consumers and civil society organizations decried the deterioration of farmers' living conditions around the world following the collapse of the ICA. International organizations and aid agencies already involved in rural development initiatives in the region started to deploy projects to help farmers confront the crisis (Linton 2005). These organizations began to label and sell fair-trade products in alternative shops in Europe, drawing attention to the plight of producers in consumer markets.

The pioneers were Transfair, the FairTrade label, and the Max Havelaar organizations that in 1997 united and formed the International Fairtrade Labeling Organization (Linton 2005). They were the creation of philanthropic individuals, in conjunction with humanitarian NGOs, that saw in trade an economically sustainable alternative to the traditional humanitarian aid channels of donations and relief. True to their belief in a more equitable society, these organizations changed their approach from a mere philanthropic endeavor to an effort to revolutionize the terms of trade of tropical commodities by reembedding the social and ecological production of coffee through new market relationships between consumers and rural households (Raynolds 2000).
A similar pathway was followed by the organic movement that sought to act as a counter-culture response to the green revolution developments in agriculture (Raynolds 2000). Producers, traders, manufacturers, and retailers of organic products joined forces under the International Federation of Organic Agriculture Movements (IFOAM), founded in Germany in 1972. The organization had been, up to the 1980s mainly concerned with promoting organic agriculture in Europe and North America. In the 1990s it expanded its reach to tackle tropical commodities, particularly coffee, but also tea, cocoa, and bananas.

Civil society organizations or nongovernmental organizations focused on environmental protections, i.e., the Smithsonian Migratory Bird Center, or on social justice issues, i.e., OXFAM, and became involved in the coffee value chain (Bitzer et al. 2008), although their core mission was not connected to commodity trading. In essence, the coffee commodity system, linked initially only via trade institutions, began to be coupled with actors, institutions, and associated values with deep interests in the same rural resource base, but until this point, operating independently of the coffee sector.

Feedback to governance

The collapse of the ICA in 1989 and the subsequent impoverishment of coffee communities around the world, brought the two independent constellations of actors, values, and associated institutional arrangements, one governing coffee, the other involved in rural social welfare, to become coupled to collectively govern coffee producing landscapes. As this coupling consolidated, international efforts were organized to specifically address market issues and social equity through institutional innovations, such as the Max Havelaar label, created under the auspices of the Dutch ecumenical development agency Solidaridad, to mainstream coffee as a fair-trade product (Fairtradenet 2017). Certification schemes in coffee had existed prior to the collapse of the ICA, but it was the market shock of 1989 that is widely interpreted as catalyzing these initiatives into new forms of coffee system governance (Bray et al. 2002). Other initiatives gained ground in the 1990s, such as the Fairtrade Foundation (Germany), Transfair (USA), the UTZ Kapeh Foundation (also from the Netherlands), the Rainforest Alliance (UK-USA), and the organic movement, under the umbrella of IFOAM (Muradian and Pelupessy 2005).

The humanitarian organizations created a space in international coffee markets, generating and responding to a demand for ethical products; larger coffee traders realized the market benefits of these grass roots institutional innovations. The result was the emergence of private governance mechanisms for sustainability, mainly certification programs that delivered technical assistance, created codes of conduct, and allowed compliant products to use a label to differentiate the product in the market (Auld et al. 2009, Auld 2010). By providing better prices and a new market outlet these programs sought to stabilize prices and support the livelihoods of coffee growers through more environmentally sound practices and explicit commitments to support labor and human rights. Certifying bodies were accredited to conduct audits and authorize the use of a seal of approval identifying products and ingredients produced according to the code criteria. Environmental and humanitarian NGOs, many of which were not previously involved in commodity chain governance, 
developed partnerships with buyers, including most of the largest coffee roasters in the market, who have made pledges to reach $100 \%$ sustainable coffee purchases before 2050 (TCC 2012).

The aggregated result of these initiatives is remarkably high: according to a recent report (Potts et al. 2014) over $40 \%$ of the total amount of coffee produced around the world is done following a sustainability certification or verification program. Nevertheless, impacts on livelihoods remain a matter of discussion with abundant research showing small or negligible impacts whereas others present a more positive picture (see, for example, Blackman and Rivera 2011, Tscharntke et al. 2015, and DeFries et al. 2017 for recent comparative analyses of studies).

In Colombia, a commission convened by the President recommended that Colombia embark on a programa de cafes especiales (program of specialty coffees) to increase the value of Colombian coffee, following the global trends observed in this market. The Colombian government was heavily interested in rescuing the coffee sector, not only because of its significance for the rural economy and tax-generating potential, but also because of the linkages between falling coffee prices and increased violence in the coffee zones resulting from welfare decline (Dube and Vargas 2013). The program was established with the intention of appropriating domestically a larger share of the value captured in the market. The three strategies through which this was going to be achieved were the following: (i) differentiating coffee production and outlets through high-quality production from specific origins or terroirs, (ii) participating in sustainability strategies, certifying production, and finding buyers for this ecofriendly coffee; and (3) competing in the cafeteria segment through the opening of the Juan Valdez ${ }^{\mathrm{TM}}$ stores in North America, Europe, but specially in Colombia and other Latin American countries (for a detailed description of the program and its achievements see Rueda and Lambin 2013a). All these strategies were executed by the Colombian Coffee Growers Federation (FNC by its Spanish acronym) that serves the more than 500,000 families who grow coffee in the country, and is in charge of managing the export tax.

The permanence of the Fondo Nacional del Café, the country's coffee board, created in 1940, was particularly instrumental in Colombia's response to changing governance conditions internationally. The Fondo collected a variable tax from coffee growers, purchasing part of the crop, and ensuring the distribution of export quotas among local exporters (FNC 2017). The Fondo has since been administered by the FNC, representing more than 500,000 families that produce coffee. Colombia has become a world leader in coffee sustainability programs, with over $60 \%$ of its supply under sustainability certification and verification schemes (Potts et al. 2014).

The demand for sustainable coffee continues to grow. The surge in demand has also translated in higher international prices (Fig. 5) that reached their highest level in 2010, but have since stabilized at about three times the value of 2001, when the crisis hit bottom. Large agribusinesses corporations in the coffee sector have embraced certification as their main sustainability strategy (TCC 2012), but it has spilled over other sectors as well. Today, all major agricultural commodities have embraced some form of market mechanisms to advance their sustainability commitments (Rueda et al. 2017). For Colombia, the growth of these market segments and therefore the success of the programa de cafés especiales has also produced significant positive outcomes for farmers and their resource base (Rueda and Lambin 2013b).

The speed and intensity of communication undergirds the new connections between consumers in the North and producers in the South, and has created a new business culture in which both social-ecological systems are linked not merely by trade, but by a set of principles and practices embraced globally and audited by external parties. As coffee producing livelihoods and environmental conditions became part of both the international aid agenda and the commodity trade, the concerns, values, and governance systems of North America and Europe have become part of the governance of coffee trade and coffee production, changing the social-ecological system in producing countries. Institutions in producing countries (particularly in Colombia) adopted and adapted the norms, values, and institutions of the social-ecological systems of consuming countries to govern the rural landscapes and livelihoods in which coffee is produced, thus furthering the coupling of the two systems, beyond trade.

\section{DISCUSSION}

The two case studies presented above, although broadly similar in terms of food system characteristics, resulted in very different outcomes in terms of food system governance. In the Mexican maize case, the new connectivity between U.S. energy policy, and grain prices and trade contributed to a significant shock in Mexican tortilla prices and economic food access. Although this event had some influence on Mexico's domestic biofuel development policy, there was no change in the governance of food and energy policy in the sending system: the U.S. Corn/ Ethanol system. In contrast, in the case of coffee, the telecoupling of coffee market and humanitarian networks internationally triggered a significant change in domestic coffee system governance in Colombia, in part because of the receptivity of Colombia's Coffee Growers Federation to the international signal. Colombia maintained its national coffee board throughout the crisis and launched an aggressive program of product differentiation. This resulted in substantial growth of the industry and significant benefits for farmers, beyond price premiums (Rueda and Lambin 2013b). Colombia's success contrasts with other coffee producing nations that failed to integrate the changing international domain of governance into national institutions. For example, Mexico was also devastated by the coffee crisis of the early 2000s yet has not been able to use the novel sustainability certification programs to rebound. Mexico defaulted its external debt in the late 1980s, forcing the establishment of neoliberal reforms that, among other things, abolished the National Institute for Coffee (INMECAFE) in 1989. Mexico was far less sensitive to the collapse of the coffee market: in 1989 , coffee represented only $1.7 \%$ of total export value compared to $20 \%$ from exports of crude petroleum. In contrast, Colombia's coffee sector represented $29 \%$ of its export value, followed by $18 \%$ from petroleum (OEC 2017). Although there are a number of cases of cooperative movements in Mexico that were able to develop and implement sustainability programs, overall, the sector has struggled and lost competitive ground (Bacon et al. 2008). By 2012, Mexico, the ninth largest producer of coffee in the world, had only $20 \%$ of its coffee under some kind of certification program. 
The two cases provide some empirical grounding to explore the circumstances, ranging from the initial conditions of distal systems, to the forms of pressures that emerge in telecoupled relationships, to the politics involved in the receptivity of incumbent governance regimes to change, under which system boundaries may expand to incorporate emergent knowledge of telecoupling consequences. System boundaries, through the lens of governance, are socially constructed (Ostrom 2009). They "are shaped by admixtures of regulative and governance arrangements; cultural-cognitive conceptions of identity and a sense of "being in the same boat"; normative and ethical frameworks that provide common rules and standards; and interdependencies borne of technical connections or dependence on similar types of natural resources" (Dacin et al. 2002:51). Telecoupling thus challenges how actors define food system boundaries for governance: the recognition of distal ties and causal linkages opens an opportunity for an expansion of what constitutes the resource units, the actors, and the institutional arrangements salient in a food system.

We found that categorizing forms of telecoupling is constructive in that it illuminates the different ways that systems may be distal, and thus the issues that must be addressed, and obstacles that may need to be overcome in order to bridge such distances to form new or expanded governance arrangements. Our typology posits that three forms of distance are particularly important to understand telecoupling: social, institutional, and physical or resource-based distance. Bridging distance entails transaction costs; one might assume then that transaction costs are likely to be diminished where existing flows and connectivities, of information, of values, of material, can be leveraged, even though these flows were not initially governed as part of the food system of concern.

In the case of the initial coupling of U.S. corn and the U.S. energy sector, and the coupling of coffee farming and humanitarian systems internationally and in Colombia specifically, the initial distance was most stark in terms of social actors and institutions: a shared resource system (land, water, physical geographies) but distinct objectives, agendas, and actors (type 3). In this configuration, alterations, or, in the case of U.S. corn and U.S. biofuels, new opportunities, in the performance of the resource system (what Dacin et al. 2002 call "functional pressures") provide a stimulus to the disparate actors associated with a specific resource system to forge new relationships and institutional ties. The expansion of governance boundaries in a type 3 case would potentially involve the incorporation of additional values and agendas, "cultural-cognitive conception" (Dacin et al. 2002), and meanings associated with the resource base into existing governance mechanisms. In the case of U.S. commodity corn, this entailed the incorporation of the energy potential of ethanol into the Farm Bill, and expanding the governance of Midwestern corn production to explicitly incorporate actors and interests associated with the energy sector. In the case of coffee, the adjustments in governance involved the incorporation of social and humanitarian values into the management of coffee production regions and the supply chain. Although these changes are not trivial, the actors at least have a common resource base of interest to aid in overcoming barriers.

In type 2 cases, where social distance is relatively small and actors are already in communication over many aspects of institutional design, the transaction costs associated bridging distal resource bases may also be surmountable (Bodin and Crona 2009). Research on social-ecological system transformation and governance has highlighted the role played by what is often termed "shadow networks": existing social networks of actors who share values and priorities (Olsson et al. 2006). Scholars have argued that transformation in governance arrangements is more likely when such shadow networks are in place, and can be mobilized to stimulate change across space, culture, and scale (Dacin et al. 2002, Brondizio et al. 2009, Bodin and Crona 2009, Duit et al. 2010). If existing actors within the existing governance arrangement are those that draw attention to the undesirable outcome of telecoupling, they may have the standing to mobilize for change within the existing governance system. Yet, as the maize case reveals, it is not enough for actors associated with two distal resource bases to be in communication and committed to similar institutional arrangements (in this case, maize market governance). The "functional pressure" of the Tortilla Crisis was only a crisis for some of the actors in the maize/corn commodity system, namely, politicians, consumers, and producers in Mexico. Clearly, asymmetries of influence within existing governance arrangements also matters: In this particular case, there was no significant incentive for the dominant actor in the maize/corn commodity system (the U.S.) to modify its policy priorities. In the case of coffee in Colombia, the national government had a significant political and economic incentive to respond proactively to mediate the impacts of the coffee crisis on rural welfare in order to stem rural violence and maintain tax revenues.

Systems that are initially distal in both social and physical dimensions (type 1) perhaps pose the greatest challenge for telecoupling governance, given the need for disparate and distal actors to find sufficient political leverage and connectivity to convince others that their values, concerns, and resource interests merit the investment in institutional change. In this case, the transaction costs to governance change are large, and change perhaps less likely, unless telecoupling not only produces changes in system performance ("functional pressure") of interest to some actors with the capacity to mobilize for their interest, but also provokes, or is accompanied by (coincidentally or not), concurrent changes that weaken the influence of the incumbent governance regime over the system in question ("political pressure") and make it amenable to change. Neither of the two cases explored here manifest what we have called type 1 telecoupling; this type is perhaps less common in the globalized world today.

Clearly it is not just the ways in which systems can be considered distal (either in terms of social, institutional, or resource systems) that matters for governance change. In some telecoupling processes, actors without any initial relation to the commodity chain are able to gain attention and influence over subsequent institutional development processes and participate in redefining not only the thematic scope of governance but also the geographic domain. The susceptibility of a system of governance to such change is related to the distribution of control and influence among stakeholders over the material and nonmaterial flows that describe a telecoupled system, reflecting their different social and political positions. Such power and agency are exhibited in, for example, the wide geographic distribution of an international NGO constituency (as in the humanitarian groups concerned 
about rural development in coffee producing areas), in the political salience of a particular social group in a policy process (as Colombia's coffee farmers represented to coffee sector governance beyond Colombia's borders, or Mexico's maize producers and consumers are in Mexico's domestic scene), and the ability of a particular actor such as the U.S. government to choose to ignore or resist effects and outcomes beyond its political boundaries.

The globalization of food systems has dramatically reduced the role of political boundaries as barriers to the mobilization capacities of nonstate actors. Private sector actors with a brand reputation to protect in a competitive market are increasingly susceptible to pressures from consumer groups regardless of origin, while public sector actors and processes are generally accountable only to citizens and domestic interest groups (Dauvergne and Lister 2013). Compared to civil society groups with exclusive domestic reach, transnational NGOs can mobilize constituents in multiple geographies. This mobilization capacity allows such actors to create social pressure in distinct geographies, not only where a problem is perceived and experienced, but also potentially where decisions regarding the problem originate. The food system is now rife with complex coalitions and networks of interest groups working across political boundaries. Coffee processors and retailers are largely concentrated in the global North, overlapping with the (coffee drinking) constituencies of international NGOs concerned about tropical deforestation, development, and social justice. However, this is not always the case; the interest groups concerned about the smallholder maize farmers and the social and environmental effects of expanded corn ethanol production in Mexico have little political standing or leverage with U.S. consumers or policy makers.

One of the overwhelming challenges in governing food systems is the diversity of values and meanings associated with food among different populations (Eakin et al. 2010). In telecoupled systems, actors may be more likely to mobilize change in governance when the impacts of telecoupling affects "boundary objects" (see Wenger 1998), e.g., coffee, tortillas, the Amazon, orangutans, or monarch butterflies, that are imbued with values that span geographic boundaries and constituencies. Coffee has a high visibility for consumers; it is associated with positive cultural and social values among producer and consumer groups in diverse countries. As an industrial input, corn for ethanol use lacks the visibility of a food product, and the deeply symbolic, cultural value associated with maize and the tortilla does not extend beyond Mexico's borders (Baker 2013). Change in governance may be less likely if the impacts of telecoupling, and thus the "pressures" for institutional change, do not resonate with the values and concerns of actors beyond those immediately experiencing the impact.

\section{CONCLUSIONS}

The globalization of food systems has increased the potential for conflict and adverse outcomes from telecoupling in food systems, given diversity of values associated with food, ecological concerns, the context within which food is produced, and the diversity of actors with competing interests and values. Our case studies suggest that the processes and outcomes of telecoupling will potentially alter food system governance, in some cases expanding governance to incorporate new values, priorities, and issues and actors into the food system, as well as the physical scope of such governance. Whether such changes in governance occur and what are their impacts for the resilience of the new socialecological systems will depend on the nature of distance in the systems in question: whether the systems are distal in terms of social and/or institutional ties, or the resource bases that are affected by telecoupling, or some combination of all three dimensions of distance. But the challenge of overcoming distance is not the only issue that affects the possibility of governance change: the cultural and economic conditions of the connected systems, the agency of actors involved and their political and social relations and networks all come to play in enabling governance transformation.

Currently, most food systems are governed primarily in terms of their economic value and via trade relationships. In many cases, the actors benefiting from these particular governance arrangements will likely have disproportionate influence and agency in any political response to a telecoupling outcome. Nevertheless, as consumer classes become more integrated and networked globally, there is increasing evidence that they are sharing perspectives, values, and social and moral ties. The existence of these parallel networks and their connectivity to food systems can play powerful roles in the transformation of food system governance. In deploying telecoupling as a heuristic in food system analysis, we demonstrate the diversity of mechanisms that stimulate food system change. The interconnections in food systems go beyond the economic: they are grounded in knowledge, ideology, finance, culture, consumer preferences, and ways of life. It is nevertheless clear that although there is a plethora of examples of new forms of food governance, many of which are reflecting sustainability principles and humanitarian concerns, the development of such governance architecture is not inevitable. The concept of telecoupling helps make the mechanisms of change more visible, and in doing so, offers opportunities to steer systems to more sustainable outcomes.

Responses to this article can be read online at: http://www.ecologyandsociety.org/issues/responses. $\mathrm{php} / 9831$

\section{Acknowledgments:}

The constructive comments of three anonymous reviewers significantly improved this manuscript. We are also appreciative of the comments offered by the participants in the Telecoupling Satellite Session of the CCS'15 Conference on Complex Systems (October 2015). Research on the Mexican maize system was supported by NSF Grant No. 0826871 ( PI H. Eakin). Anyopinions, findings and conclusions or recommendations expressed in this material are those of the authors and do not necessarily reflect the views of the National Science Foundation (NSF).

\section{LITERATURE CITED}

Adger, W. N., H. Eakin, and A. Winkels. 2009. Nested and networked vulnerabilities to environmental change. Frontiers in Ecology and the Environment 7(3):150-157. http://dx.doi. org/10.1890/070148 
Appendini, K. 2014. Reconstructing the maize market in rural Mexico. Journal of Agrarian Change 14(1):1-25. http://dx.doi. org/10.1111/joac. 12013

Auld, G. 2010. Assessing certification as governance: effects and broader consequences for coffee. Journal of Environment \& Development 19(2):215-241. http://dx.doi.org/10.1177/1070496510368506

Auld, G., C. Balboa, S. Bernstein, and B. Cashore. 2009. The emergence of non-state market-driven (NSMD) global environmental governance: a cross-sectoral assessment. Pages 183-218 in M. A. Delmas and O. R. Young, editors. Governance for the environment: new perspectives. Cambridge University Press, Cambridge, UK. http://dx.doi.org/10.1017/

CBO9780511627170.009

Austin, J. E., and G. Esteva. 1987. Food policy in Mexico: the search for self-sufficiency. Cornell University Press, Ithaca, New York, USA.

Bäckstrand, K. 2006. Multi-stakeholder partnerships for sustainable development: rethinking legitimacy, accountability, and effectiveness. Environmental Policy and Governance 16 (5):290-306. http://dx.doi.org/10.1002/eet.425

Bacon, C. M., V. E. Mendez, S. R. Gliessman, D. Goodman, J. A. Fox, editors. 2008. Confronting the coffee crisis: fair trade, sustainable livelihoods and ecosystems in Mexico and Central America. MIT Press, Cambridge, Massachusetts, USA. http://dx. doi.org/10.7551/mitpress/9780262026338.001.0001

Baker, L. E. 2013. Corn meets maize: food movements and markets in Mexico. Rowman and Littlefield, Plymouth, UK.

Bitzer, V., M. Francken, and P. Glasbergen. 2008. Intersectoral partnerships for a sustainable coffee chain: really addressing sustainability or just picking (coffee) cherries? Global Environmental Change 18(2):271-284. http://dx.doi.org/10.1016/ j.gloenvcha.2008.01.002

Blackman, A., and J. Rivera. 2011. Producer-level benefits of sustainability certification. Conservation Biology 25(6):1176-1185. http://dx.doi.org/10.1111/j.1523-1739.2011.01774.x

Bodin, Ö., and B. I. Crona. 2009. The role of social networks in natural resource governance: what relational patterns make a difference? Global Environmental Change 19(3):366-374. http:// dx.doi.org/10.1016/j.gloenvcha.2009.05.002

Boons, F., and A. Mendoza. 2010. Constructing sustainable palm oil: how actors define sustainability. Journal of Cleaner Production 18(16-17):1686-1695. http://dx.doi.org/10.1016/j.jclepro.2010.07.003

Borras Jr, S. M., and J. C. Franco. 2012. Global land grabbing and trajectories of agrarian change: a preliminary analysis. Journal of Agrarian Change 12(1):34-59. http://dx.doi. org/10.1111/j.1471-0366.2011.00339.x

Bray, D. B., J. L. P. Sánchez, and E. C. Murphy. 2002. Social dimensions of organic coffee production in Mexico: lessons for eco-labeling initiatives. Society \& Natural Resources 15 (5):429-446. http://dx.doi.org/10.1080/08941920252866783

Brondizio, E. S., E. Ostrom, and O. R. Young. 2009. Connectivity and the governance of multilevel social-ecological systems: the role of social capital. Annual Review of Environment and Resources 34:253-278. http://dx.doi.org/10.1146/annurev.environ.020708.100707
Byerlee, D., and X. Rueda. 2015. From public to private standards for tropical commodities: a century of global discourse on land governance on the forest frontier. Forests 6(4):1301-1324. http:// dx.doi.org/10.3390/f6041301

Campbell, H. 2009. Breaking new ground in food regime theory: corporate environmentalism, ecological feedbacks and the 'food from somewhere' regime? Agriculture and Human Values 26 (4):309-319. http://dx.doi.org/10.1007/s10460-009-9215-8

Cárdenas, M. 1993. Comentarios al tema. Economía cafetera: crisis y perspectivas 153 .

Challies, E., J. Newig, and A. Lenschow. 2014. What role for social-ecological systems research in governing global teleconnections? Global Environmental Change 27:32-40. http:// dx.doi.org/10.1016/j.gloenvcha.2014.04.015

Clapp, J. 2003. Transnational corporate interests and global environmental governance: negotiating rules for agricultural biotechnology and chemicals. Environmental Politics 12:1-23. http://dx.doi.org/10.1080/09644010412331308354

Clapp, J. 2009. Food price volatility and vulnerability in the Global South: considering the global economic context. Third World Quarterly 30(6):1183-1196. http://dx.doi.org/10.1080/014$\underline{36590903037481}$

Dacin, M. T., J. Goodstein, and W. R. Scott. 2002. Institutional theory and institutional change: introduction to the special research forum. Academy of Management Journal 45(1):45-56. http://dx.doi.org/10.5465/AMJ.2002.6283388

Dauvergne, P., and J. Lister. 2013. Eco-business: a big-brand takeover of sustainability. MIT Press, Cambridge, Massachusetts, USA.

Davenport, F., D. G. Steigerwald, and S. Sweeney. 2016. Open trade, price supports, and regional price behavior in Mexican maize markets. Economic Geography 92(2):201-225. http://dx.doi. org/10.1080/00130095.2015.1112731

DeFries, R. S., J. Fanzo, P. Mondal, R. Remans, and S. A. Wood. 2017. Is voluntary certification of tropical agricultural commodities achieving sustainability goals for small-scale producers? A review of the evidence. Environmental Research Letters 12(3):033001. http://dx.doi.org/10.1088/1748-9326/aa625e

Dube, O., and J. F. Vargas. 2013. Commodity price shocks and civil conflict: evidence from Colombia. Review of Economic Studies 80(4):1384-1421. http://dx.doi.org/10.1093/restud/rdt009

Duit, A., V. Galaz, K. Eckerberg, and J. Ebbesson. 2010. Governance, complexity, and resilience. Global Environmental Change 20(3):363-368. http://dx.doi.org/10.1016/j.gloenvcha.2010.04.006

Eakin, H., J. Bausch, and S. Sweeney. 2014b. Agrarian winners of neoliberal reform: The "maize boom" of Sinaloa, Mexico. Journal of Agrarian Change 14(1):26-51. http://dx.doi. org/10.1111/joac.12005

Eakin, H., H. G. Bohle, A. M. Izac, A. Reenberg, P. Gregory, and L. Pereira. 2010. Food, violence and human rights, Pages 245-271 in J. Ingram, P. Ericksen, and D. Liverman, editors. Food security and global environmental change. Earthscan, London, UK. 
Eakin, H., R. DeFries, S. Kerr, E. F. Lambin, J. G. Liu, P. J. Marcotullio, P. Messerli, A. Reenberg, X. Rueda, S. R. Swaffield, B. Wicke, and K. Zimmerer. 2014a. Significance of telecoupling for exploration of land use change. Pages 141-462 in K. C. Seto and A. Reenberg, editors. Rethinking global land use in an urban era. MIT Press, Cambridge, Massachusetts, USA. http://dx.doi. org/10.7551/mitpress/9780262026901.003.0008

Eakin, H., and M. Wehbe. 2009. Linking local vulnerability to system sustainability in a resilience framework: two cases from Latin America. Climatic Change 93:355-377. http://dx.doi. org/10.1007/s10584-008-9514-X

Eakin, H., A. Winkels, and J. Sendzimir. 2009. Nested vulnerability: exploring cross-scale linkages and vulnerability teleconnections in Mexican and Vietnamese coffee systems. Environmental Science and Policy 12(4):398-412. http://dx.doi. org/10.1016/j.envsci.2008.09.003

Ericksen, P. J. 2008. Conceptualizing food systems for global environmental change research. Global Environmental Change 18 (1):234-245. http://dx.doi.org/10.1016/j.gloenvcha.2007.09.002

Fairtradenet. 2017. History of fairtrade. Fairtrade International, Bonn, Germany. [online] URL: https://www.fairtrade.net/aboutfairtrade/history-of-fairtrade.html

Federación Nacional de Cafeteros (FNC). 2017. Contrato de administración del Fondo Nacional del Café. FNC, Bogotá, Colombia. [online] URL: https://www.federaciondecafeteros. org/static/files/Contrato administracion FoNC.pdf

Foley, J. A., N. Ramankutty, K. A. Brauman, E. S. Cassidy, J. S. Gerber, M. Johnston, N. D. Mueller, C. O'Connell, D. K. Ray, P. C. West, C. Balzer, E. M. Bennett, S. R. Carpenter, J. Hill, C. Monfreda, S. Polasky, J. Rockstrom, J. Sheehan, S. Siebert, D. Tilman, and D. P. M. Zaks. 2011. Solutions for a cultivated planet. Nature 478:337-342. http://dx.doi.org/10.1038/nature10452

Franks, D. M., R. Davis, A. J. Bebbington, S. H. Ali, D. Kemp, and M. Scurrah. 2014. Conflict translates environmental and social risk into business costs. Proceedings of the National Academy of Sciences 111(21):7576-7581. http://dx.doi.org/10.1073/ pnas. 1405135111

Fraser, E. D., W. Mabee, and F. Figge. 2005. A framework for assessing the vulnerability of food systems to future shocks. Futures 37(6):465-479. http://dx.doi.org/10.1016/j.futures.2004.10.011

Friedmann, H. 1994. Distance and durability: shaky foundations of the world food economy. Pages 258-276 in P. McMichael, editor. The global restructuring of agro food systems. Cornell University Press, Ithaca, New York, USA.

Friis, C., and J. Ø. Nielsen. 2017. On the system. Boundary choices, implications, and solutions in telecoupling land use change research. Sustainability 9(6):974. https://doi.org/10.3390/ $\underline{\text { su9060974 }}$

Fuchs, D., A. Kalfagianni, and T. Havinga. 2011. Actors in private food governance: the legitimacy of retail standards and multistakeholder initiatives with civil society participation. Agriculture and Human Values 28(3):353-367. http://dx.doi. org/10.1007/s10460-009-9236-3
Gereffi, G., J. Humphrey, and T. Sturgeon. 2005. The governance of global value chains. Review of International Political Economy 12:78-104. http://dx.doi.org/10.1080/09692290500049805

Giovannucci, D., and S. Ponte. 2005. Standards as a new form of social contract? Sustainability initiatives in the coffee industry. Food Policy 30:284-301. http://dx.doi.org/10.1016/j.foodpol.2005.05.007

Godfray, H. C. J., J. R. Beddington, I. R. Crute, L. Haddad, D. Lawrence, J. F. Muir, J. Pretty, S. Robinson, S. M. Thomas, and C. Toulmin. 2010. Food security: the challenge of feeding 9 billion people. Science 327:812-818. http://dx.doi.org/10.1126/science.1185383

González, G., G. Romero, G. Pérez Silva, M. Pérez, K. Avilés, C. Gómez, and R. Llanos. 2007. Caos en el precio de la tortilla; llegó a \$30 en Durango y 18 en Baja California. La Jornada, 11 January. [online] URL: http://jornada.unam.mx/2007/01/11/index.php? $\underline{\text { section }=\text { economia } \& \text { article }=019 \mathrm{n} 1 \text { eco }}$

González Merino, A., and Y. Casteñeda Zavala. 2008. Biocombustibles, biotecnología y alimentos: Impactos sociales para México. Nueva Época 21(57):55-83.

Goodman, D., and M. Watts, editors. 1997. Globalising food: agrarian questions and global restructuring. Routledge, London, UK.

Goodman, M. K., D. Maye, and L. Holloway. 2010. Ethical foodscapes? Premises, promises, and possibilities. Environment and Planning A 42:1782-1796. http://dx.doi.org/10.1068/a43290

Headey, D. 2011. Rethinking the global food crisis: the role of trade shocks. Food Policy 36(2):136-146. http://dx.doi. org/10.1016/j.foodpol.2010.10.003

Hill, J., E. Nelson, D. Tilman, S. Polasky, and D. Tiffany. 2006. Environmental, economic and energetic costs and benefits of biodiesel and ethanol biofuels. Proceedings of the National Academy of Sciences 103(30):11206-11210. http://dx.doi. org/10.1073/pnas.0604600103

Hoffman, L., A. Baker, L. Foreman, and C. E. Young. 2007. Feed grains backgrounder. U.S. Department of Agriculture Economic Research Service, Washington, D.C., USA.

Ingram, J., P. Ericksen, and D. Liverman. 2010. Food security and global environmental change. Earthscan, London, UK.

International Coffee Association (ICO). Daily coffee prices. ICO, London, UK. [online] URL: http://www.ico.org/coffee prices. asp

Institute for Agriculture and Trade Policy (IATP) Trade and Global Governance Program. 2008. Commodities market speculation: the risk to food security and agriculture. Institute for Agriculture and Trade Policy, Minneapolis, Minnesota, USA.

International Coffee Organization (ICO). 2017. Daily coffee prices. ICO, London, UK. [online] URL: http://www.ico.org/ coffee prices.asp

Jaffee, S., and S. Henson. 2004. Standards and agro-food exports from developing countries: rebalancing the debate. World Bank Policy Research Working Paper. World Bank, Washington, D.C., USA. 
Jaquet, S., G. Shrestha, T. Kholer, and G. Schwilch. 2016. The effects of migration of livelihoods, land management, and vulnerability to natural disasters in the Harpan watershed in western Nepal. Mountain Research and Development 36 (4):494-505. http://dx.doi.org/10.1659/MRD-JOURNAL-D-16-00034.1

Karkkainen, B. C. 2003. Post-sovereign environmental governance: the collaborative problem-solving model. PIK Report 80:206-216.

Keleman, A., and H. García Rañó. 2011. The Mexican tortilla crisis of 2007: the impacts of grain-price increases on foodproduction chains. Development in Practice 21(4-5):550-565. http://dx.doi.org/10.1080/09614524.2011.562487

Lambin, E. F., and P. Meyfroidt. 2011. Global land use change, economic globalization, and the looming land scarcity. Proceedings of the National Academy of Sciences 108 (9):3465-3472. http://dx.doi.org/10.1073/pnas.1100480108

Lee, J., G. Gereffi, and J. Beauvais. 2012. Global value chains and agrifood standards: challenges and possibilities for smallholders in developing countries. Proceedings of the National Academy of Sciences 109(31):12326-12331. http://dx.doi.org/10.1073/pnas.0913714108

Lemos, M. C., and A. Agrawal. 2006. Environmental governance. Annual Review of Environment and Resources 31:297-325. http:// dx.doi.org/10.1146/annurev.energy.31.042605.135621

Lerner, A. M., and H. Eakin. 2011. An obsolete dichotomy? Rethinking the rural-urban interface in terms of food security and production in the global south. Geographical Journal 177 (4):311-320. http://dx.doi.org/10.1111/j.1475-4959.2010.00394.x

Linton, A. 2005. Partnering for sustainability: business-NGO alliances in the coffee industry. Development in Practice 15 (3-4):600-614. http://dx.doi.org/10.1080/09614520500075664

Liu, J., V. Hull, M. Batistella, R. DeFries, T. Dietz, F. Fu, T. W. Hertel, R. C. Izaurralde, E. F. Lambin, S. Li, L. A. Martinelli, W. J. McConnell, E. F. Moran, R. Naylor, Z. Ouyang, K. R. Polenske, A. Reenberg, G. de Miranda Rocha, C. S. Simmons, P. H. Verburg, P. M. Vitousek, F. Zhang, and C. Zhu. 2013. Framing sustainability in a telecoupled world. Ecology and Society 18 (2):26. http://dx.doi.org/10.5751/ES-05873-180226

Mayer, F., and G. Gereffi. 2010. Regulation and economic globalization: prospects and limits of private governance. Business and Politics 12(3):1-25. http://dx.doi.org/10.2202/1469-3569.1325

McMichael, P. 2001. The impact of globalisation, free trade and technology on food and nutrition in the new millennium. Proceedings of the Nutrition Society 60(2):215-220. http://dx.doi. org/10.1079/PNS200088

McMichael, P. 2009. A food regime genealogy. Journal of Peasant Studies 36(1):139-169. http://dx.doi.org/10.1080/03066150902820354

McMichael, P. 2011. Food system sustainability: questions of environmental governance in the new world (dis)order. Global Environmental Change 21(3):804-812. http://dx.doi.org/10.1016/ j.gloenvcha.2011.03.016

McPhail, L., and X. Du. 2012. Ethanol strengthens the link between agriculture and energy markets. Amber Waves, 2 June. [online] URL: https://ageconsearch.umn.edu/bitstream/145583/-
2/10Ethanol $\% 20$ Strengthens $\% 20$ the $\% 20$ Link $^{2} \% 20$ Between $\%$ 20Agriculture $\% 20$ and $\% 20$ Energy.pdf

Melgar, I., and J. Contreras. 2008. Afina el Presidente plan nacional ante crisis alimentaria. El Excelsior, 23 May.

Mena, S., and G. Palazzo. 2012. Input and output legitimacy of multi-stakeholder initiatives. Business Ethics Quarterly 22 (3):527-556 http://dx.doi.org/10.5840/beq201222333

Moser, S. C., and J. A. F. Hart. 2015. The long arm of climate change: societal teleconnections and the future of climate change impacts studies. Climatic Change 129(1-2):13-26. http://dx.doi. org/10.1007/s10584-015-1328-Z

Muñoz Ríos, P. 2007. En México no se debe usar el maíz como biocombustible, afirman ONG. La Jornada, 14 September. [online] URL: http://www.jornada.unam.mx/2007/09/14/index. php? section $=$ sociedad $\&$ article $=045 \mathrm{n} 1 \mathrm{soc}$

Muradian, R., and W. Pelupessy. 2005. Governing the coffee chain: the role of voluntary regulatory systems. World Development 33(12):2029-2044. http://dx.doi.org/10.1016/j. worlddev.2005.06.007

Newton, P., A. Agrawal, and L. Wollenberg. 2013. Enhancing the sustainability of commodity supply chains in tropical forest and agricultural landscapes. Global Environmental Change 23 (6):1761-1772. http://dx.doi.org/10.1016/j.gloenvcha.2013.08.004

Observatory of Economic Complexity (OEC). 2017. What does Colombia export? (1989). Massachusetts Institute of Technology, Cambridge, Massachusetts, USA. [online] URL: http://atlas. media.mit.edu/en/visualize/tree map/sitc/export/col/all/show/1989/

Oliver, C. 1997. Sustainable competitive advantage: combining institutional and resource-based views. Strategic Management Journal 18:697-713. http://dx.doi.org/10.1002/(SICI)1097-0266 (199710)18:9<697::AID-SMJ909>3.0.CO;2-C

Olsson, P., L. H. Gunderson, S. R. Carpenter, P. Ryan, L. Lebel, C. Folke, and C. S. Holling. 2006. Shooting the rapids: navigating transitions to adaptive governance of social-ecological systems. Ecology and Society 11(1):18. http://dx.doi.org/10.5751/ ES-01595-110118

Oosterveer, P., B. E. Adjei, S. Vellema, and M. Slingerland. 2014. Global sustainability standards and food security: exploring unintended effects of voluntary certification in palm oil. Global Food Security 3(3-4):220-226. http://dx.doi.org/10.1016/j. gfs. 2014.09.006

Ostrom, E. 2009. A general framework for analyzing the sustainability of social-ecological systems. Science 24:419-422. http://dx.doi.org/10.1126/science.1172133

Paulmann, J. 2013. Conjunctures in the history of international humanitarian aid during the twentieth century. Humanity: An International Journal of Human Rights, Humanitarianism, and Development 4(2):215-238. http://dx.doi.org/10.1353/hum.2013.0016

Perfetti del Corral, M., L. V. Martinez, O. A. O. Gonzáles, J. F. Hernández-Ortiz, and P. R. Arango Giraldo. 2002. Cuantificación de los impactos micro-macroeconómicos y sociales de la crisis cafetera en Colombia. Ensayos Sobre 
Economía Cafetera 18:49-59. [online] URL: https://www. federaciondecafeteros.org/static/files/1.articulocrisiscafetera-crece. pdf

Piesse, J., and C. Thirtle. 2009. Three bubbles and a panic: an explanatory review of recent food commodity price events. Food Policy 34(2):119-129. http://dx.doi.org/10.1016/j.foodpol.2009.01.001

Piperno, D. R., and K. V. Flannery. 2001. The earliest archaeological maize (Zea mays L.) from highland Mexico: new accelerator mass spectrometry dates and their implications. Proceedings of the National Academy of Sciences 98(4):2101-2103. http://dx.doi.org/10.1073/pnas.98.4.2101

Ponte, S. 2002. The coffee crisis. Centre for Development Research, Copenhagen, Denmark.

Potts, J., M. Lynch, A. Wilkings, G. A. Huppé, M. Cunningham, and V. A. Voora. 2014. The state of sustainability initiatives review 2014: standards and the green economy. International Institute for Sustainable Development, Winnepeg, Manitoba, Canada.

Raynolds, L. T. 2000. Re-embedding global agriculture: the international organic and fair trade movements. Agriculture and Human Values 17(3):297-309. http://dx.doi.org/10.1023/A:1007608805843

Reyes Guzmán, G. 2007. Incremento en los precios del maíz y la tortilla en México. Problemas del Desarrollo 38(151):103-126.

Rockström, J., W. Steffen, K. Noone, Å. Persson, F. S. Chapin, E. F. Lambin, T. M. Lenton, M. Schefoer, C. Folke, H. J. Schellnhuber, B. Nykvist, C. A. deWit, T. Huges, S. van der Leeuw, H. Rodhe, S. Sörlin, P. K. Snyder, R. Costanza, U. Svedin, M. Falkenmark, L. Karlberg, R. W. Corell, V. J. Fabry, J. Hansen, B. Walker, D. Liverman, K. Richardson, P. Crutzen, and J. A. Foley. 2009. A safe operating space for humanity. Nature 461:472-475. http://dx.doi.org/10.1038/461472a

Rueda, X., R. D. Garrett, and E. F. Lambin. 2017. Corporate investments in supply chain sustainability: selecting instruments in the agri-food industry. Journal of Cleaner Production 142:2480-2492. http://dx.doi.org/10.1016/j.jclepro.2016.11.026

Rueda, X., and E. F. Lambin. 2013a. Linking globalization to local land uses: how eco-consumers and gourmands are changing the Colombian coffee landscapes. World Development 41:286-301. http://dx.doi.org/10.1016/j.worlddev.2012.05.018

Rueda, X., and E. F. Lambin. 2013b. Responding to globalization: impacts of certification on Colombian small-scale coffee growers. Ecology and Society 18(3):21. http://dx.doi.org/10.5751/ ES-05595-180321

Secretaria de Agricultura, Ganaderia, Desarrollo Rural y Pequería (SAGARPA). 2007. Situación Actual y Perspectivas del Maíz en México. SAGARPA (SIAP), México City, Mexico.

Servicio de Información Agroalimentaria y Pequera (SIAP). 2017. Anuario Estadístico de la Producción Agrícola (Maíz grano, Zea Mays). Secretaria de Agricultural, Ganaderia, Desarrollo Rural, Pesca y Alimentación. Mexico City, Mexico.

Seto, K. C., A. Reenberg, C. G. Boone, M. Fragkias, D. Haase, T. Langanke, P. Marcotullio, D. K. Munroe, B. Olah, and D. Simon. 2012. Urban land teleconnections and sustainability.
Proceedings of the National Academy of Sciences 109 (20):7687-7692. http://dx.doi.org/10.1073/pnas.1117622109

Short, A. G. 2013. Governing change: land-use change and the prevention of nonpoint source pollution in the North Coastal Basin of California. Environmental Management 51(1):108-125. http://dx.doi.org/10.1007/s00267-011-9729-x

Sikor, T., G. Auld, A. J. Bebbington, T. A. Benjaminsen, B. S. Gentry, C. Hunsberger, A. M. Izac, M. E. Margulis, T. Plieninger, H. Schroeder, and C. Upton. 2013. Global land governance: from territory to flow? Current Opinion on Sustainability 5(5):522-527. http://dx.doi.org/10.1016/j.cosust.2013.06.006

Sweeney, S., D. G. Steigerwald, F. Davenport, and H. Eakin. 2013. Mexican maize production: evolving organizational and spatial structures since 1980. Applied Geography 39:78-92. http://dx.doi. org/10.1016/j.apgeog.2012.12.005

Taxpayers for Common Sense. 2013. Political footprint of the corn ethanol lobby. Taxpayers for Common Sense, Washington, D.C., USA.

Tropical Commodity Coalition (TCC). 2012. Coffee barometer. TCC, The Hague, The Netherlands. [online] URL: https://issuu. com/spanhuysen/docs/ttc coffeebarometer

Tscharntke, T., J. C. Milder, G. Schroth, Y. Clough, F. DeClerck, A. Waldron, R. Rice, and J. Ghazoul. 2015. Conserving biodiversity through certification of tropical agroforestry crops at local and landscape scales. Conservation Letters 8(1):14-23. http://dx.doi.org/10.1111/conl.12110

United Nations Conference on Trade and Development (UNCTAD). 2009. World investment report: transnational corporations, agricultural production and development. United Nations, Geneva, Switzerland.

U.S. Department of Agriculture Economic Research Service (USDA ERS). [various years]. Feed grains database. United States Department of Agriculture, Washington, D.C., USA.

U.S. Department of Labor, Bureau of Labor Statistics. Consumer price index. U.S. Bureau of Labor Statistics, Washington, D.C., USA. [online] URL: https://www.bls.gov/cpi/

Varangis, P., P. Siegel, D. Giovannucci, and B. Lewin. 2003. Dealing with the coffee crisis in Central America: impacts and strategies. Policy Research Working Paper No. 2993. The World Bank, Washington, D.C., USA. http://dx.doi.org/10.1596/1813-9450-2993

Verburg, P. H., K.-H. Erb, O. Mertz, and G. Espindola. 2013. Land system science: between global challenges and local realities. Current Opinion in Environmental Sustainability 5(5):433-437. http://dx.doi.org/10.1016/j.cosust.2013.08.001

Von Braun, J. 2007. The world food situation: new driving forces and required actions. Biannual Overview of the World Food Situation. International Food Policy Research Institute, Washington, D.C., USA.

Webber, J. 2017. Rising price of tortillas piles pressure on Mexico. Financial Times, 12 January. [online] URL: https://www.ft.com/ content/d2b73384-d7c1-11e6-944b-e7eb37a6aa8e 
Wenger, E. 1998. Communities of practice: learning, meaning, and identity. Cambridge University Press, Cambridge, UK. http://dx. doi.org/10.1017/CBO9780511803932

Wise, T. 2012. The cost to Mexico of U.S. corn ethanol expansion. Global Development and Environment Institute, Working Paper No. 12-01. Tufts University, Medford, Massachusetts, USA.

Young, O. R., F. Berkhout, G. C. Gallopin, M. A. Janssen, E. Ostrom, and S. van der Leeuw. 2006. The globalization of socioecological systems: an agenda for scientific research. Global Environmental Change 16(3):304-316. http://dx.doi.org/10.1016/ j.gloenvcha.2006.03.004 